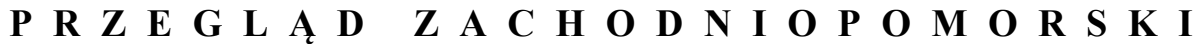 ROCZNIK XXXIII (LXII) ROK 2018 ZESZYT 1
}

\author{
Zygmunt SzultKa \\ Słupsk \\ e-mail: zygmuntszultka@wp.pl
}

\section{Elementarne SZKoly WIEJSKIE FINANSOWANe Z FUNDUSZU SZKolnego Na Pomorzu PRUSKIM W LATACH 1777-1807}

Słowa kluczowe: Pomorze pruskie w XVIII wieku, szkolnictwo wiejskie, szkoły łaski Keywords: Prussian Pomerania in the $18^{\text {th }}$ century, rural educational system, schools of grace

Trzeba stwierdzić, że szkoły określone w tytule, zwane też szkołami łaski (Gnaden-Schulen) przez współczesnych - władze i społeczeństwo - były traktowane jako specjalne. Wyróżniały się przede wszystkim tym, że były finansowane z państwowego funduszu szkolnego i dlatego ich nauczyciele byli z reguły dobrze uposażeni. Większość z nich miała wyższe od przeciętnych kwalifikacje pedagogiczne i status państwowego nauczyciela kwalifikacyjnego, zaś same szkoły - jak na koniec XVIII wieku - były dobrze zorganizowane i wyposażone $\mathrm{w}$ pomoce nauczania i podręczniki. W praktyce miały być wzorcowymi placówkami wychowawczo-oświatowymi na wsi, choć stanowiły zaledwie około 6\% ogólnej liczby szkół wiejskich Pomorza pruskiego na przełomie XVIII-XIX wieku. Z tych też powodów zwracały uwagę ówczesnych dziejopisów Pomorza pruskiego i budzą zainteresowanie badaczy do dzisiaj, ale dotąd nie doczekały się pełniejszego opracowania. Niniejsze spostrzeżenia też nie wyczerpują tej problematyki, stanowią bowiem jedynie pierwszą próbę zarysu wybranych zagadnień.

Najwcześniejszy i najpoważniejszy jest niewątpliwie głos dziejopisa Pomorza pruskiego, radcy (pracownika) Konsystorza Ewangelickiego w Szczecinie, mającego z nimi bliższy lub luźniejszy kontakt przez ćwierćwiecze, Ludwiga W. 
Brüggemanna (1743-1817), który pisał, że król pruski Fryderyk II (1740-1786) przeznaczył na pensje dla nauczycieli Pomorza dwuprocentowe odsetki od 248 637 talarów funduszu melioracyjnego, stanowiące specjalny fundusz szkolny, wynoszący rocznie w pewnym okresie 4972 talary. Jego wielkość w następnych latach, po stronie przychodów i wydatków, ulegała niewielkim zmianom, gdyż opłacano z niego również dom wychowawczy szlachcianek w Słupsku, nauczycieli seminarium nauczycielskiego w Szczecinie oraz sześciu jego preparandystów, rendanta Pomorskiej Kasy Wojennej. Najcenniejszy jest wykaz szkół łaski z 1804 roku$^{1}$. Inny dziejopis Pomorza pruskiego, lektor i wychowawca w szkole kadetów w Słupsku (1769-1811), Christian F. Wutstrack pisał, że odsetki od funduszu melioracyjnego wynosiły rocznie 4652 talarów i były dzielone przez szczeciński Konsystorz wśród nauczycieli, otrzymujących pensje roczne od 40 do 80 talarów. Dodał również, że Fryderyk II nakazał budować nowe budynki szkolne i remontować stare, usuwać ze szkół nauczycieli nieprzydatnych i zastępować ich zdolniejszymi. Podkreślił, że fundusz szkolny był zbyt niski i dlatego nie mógł spowodować ogólnej poprawy stanu szkolnictwa wiejskiego².

Autor pierwszej próby zarysu szkolnictwa na Pomorzu od XII do początków XIX wieku, ze szczególnym uwzględnieniem okresu postreformacyjnego, radca szkolny i dyrektor gimnazjum w Szczecinie, Friedrich Koch zasadniczo powtórzył przekaz Wutstracka, w niektórych fragmentach go poszerzając. Pisał bowiem, że pensje nauczycieli łaski kształtowały się w granicach 36-72 talarów, zaś król pruski w 1780 roku przeznaczył z odsetek funduszu melioracyjnego kwotę 7350 talarów na budowę 49 szkół wiejskich. Chwalił też Fryderyka II za desygnowanie w 1783 roku 144 talarów na rzecz szczecińskiego seminarium nauczycielskiego, gdyż jego absolwenci mieli zastąpić nauczycieli-inwalidów wojennych, którzy zdaniem króla okazali się „,bezsilnym wsparciem” szkół. Dodał też, że pragnieniem króla było, aby nauczyciele na Pomorzu pruskim zwiększyli swe dochody przez uprawę drzewa morwowego i hodowlę jedwabników³.

$\mathrm{Z}$ tego krótkiego przeglądu najwcześniejszych wypowiedzi o pomorskich „szkołach łaski” widać, że - chociaż stanowiły one zaledwie niewielką część

1 L.W. Brüggemann, Beiträge zu der ausführliche Beschreibung des Königl. Preußischen Herzogthums Vor- und Hinter-Pommern, Stettin 1806, s. 349-350.

2 Ch.F. Wutstrack, Kurze historisch-geographisch-statistische Beschreibung von königlich-preussischen Herzogthume Vor- und Hinter-Pommern, Stettin 1793, s. 261.

3 F. Koch, Fürst Und die Schule; oder über die Verdienste Pommerschen Fürsten um die Schulen ihres Landes, Stettin 1821, s. 48-49. 
wiejskich szkół elementarnych na Pomorzu pruskim w końcu XVIII wieku - faktycznie wiązały się z całokształtem fryderycjańskiej koncepcji systemu oświatowego, w tym takich problemów jak: wzrastająca rola państwa w funkcjonowaniu szkolnictwa, stosunek i nadzór państwa i Kościoła nad szkolnictwem, podstawy prawne i finansowe, dobór kadr, metod i treści nauczania. Jednym słowem znalazły się w centrum szerokiego wachlarza złożonych problemów pruskiego systemu szkolnictwa elementarnego Pomorza pruskiego przełomu XVIII/XIX wieku, ale - jak całe szkolnictwo pomorskie - większego rezonansu wśród badaczy nie wywołało.

Stosunek Martina Wehrmanna, który wniósł najpoważniejszy wkład w poznanie szkolnictwa pomorskiego czasów nowożytnych wobec działan Fryderyka II na rzecz rozwoju oświaty, zwłaszcza szkolnictwa wiejskiego, był wstrzemięźliwy. W „Geschichte von Pommern”" utrzymywał, że z oceną trzeba się powstrzymać, bo nie pozwalają na nią niedostatki w stanie badań. On też przedstawił genezę i okoliczności powołania na Pomorzu pruskim szkół łaski, które rozpatrywał w kontekście generalnego regulaminu szkolnego z 12 sierpnia 1763 roku oraz doświadczeń wyniesionych przez króla w czasie wojny siedmioletniej5.

Bezwzględnie najwięcej miejsca szkołom łaski na Pomorzu pruskim poświęcił zasłużony i krytyczny badacz szkolnictwa pruskiego okresu Fryderyka II - Ferdinand Vollmer, który dostrzegł ich pozytywne następstwa, ale wyraźnie też podkreślił, że nie były one w stanie zmienić pomorskiej mizerii wiejskich szkół elementarnych ${ }^{6}$. Całkowitym natomiast niepowodzeniem zakończyła się

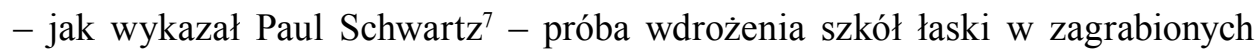
Polsce Prusach Zachodnich, gdzie miały one być lokomotywą procesów germanizacyjnych.

Problem szkół łaski znalazł też odbicie w bardzo bogatej powojennej literaturze niemieckiej dotyczącej rozwoju oświaty w państwie pruskim w XVIII wieku, rozpatrującej je najczęściej w kontekście zaangażowania państwa w finansowanie

${ }^{4}$ M. Wehrmann, Geschichte von Pommern, Bd. II, Gotha 1906, s. 241.

5 M. Wehrmann, Schulwesen im Neustettiner Kreise im Jahre 1773, Unserer Heimat-Museum 22, 1928, nr 9-10, s. 2-3.

${ }^{6}$ F. Vollmer, Die preußische Volksschulpolitik unter Friedrich dem Größen, Berlin 1918, s. $145-148,160,168$.

7 P. Schwartz, Der erste Kulturkampf in Preussen um Kirche und Schule (1788-1798), Berlin 1925; tenże, Die Schulen der Provinz Westpreußen unter dem Oberschulkollegium 1787-1806, „Zeitschrift für Geschichte der Erziehung und der Unterrichts” 1926, nr 16. 
systemu szkolnego. Zasadniczo wszyscy badacze mówią jednym głosem; bardzo krytycznie oceniają pomoc państwa w finansowanie systemu oświaty w całym tym stuleciu. Fryderyk II, który nie szczędził środków na szkolnictwo wojskowe, dopiero na początku lat siedemdziesiątych XVIII wieku dostrzegł potrzebę wsparcia materialnego szkolnictwa, ale tylko trzech prowincji, mianowicie Marchii Elektorskiej (1771), Pomorza (1773) i Prus Zachodnich (1776). Przeznaczone środki w każdym przypadku były jednak tak niskie, że miały symboliczne, a nie realne znaczenie (nie dotyczy Prus Zachodnich), gdyż celem szkoły elementarnej było dyscyplinowanie społeczeństwa i podtrzymywanie istniejącego systemu społeczno-politycznego. Dopiero gdy dojrzano w szkole korzyści ekonomiczne, mogła również liczyć na okazjonalną pomoc finansową lub materialną. Wolfgang Neugebauer, który przeanalizował problem wsparcia finansowego systemu oświaty w drugiej połowie XVIII wieku stwierdził wprost, że w dotychczasowej literaturze wielokrotnie przeceniano nie tylko środki przeznaczone na rzecz szkół łaski, ale również same szkoły ${ }^{8}$. Odnotować należy, że wypowiedzi badaczy na temat wysokości sum przeznaczonych dla nauczycieli szkół łaski oraz ich liczby są bardzo zróżnicowane, co wynikało - dodajmy - z niezgodności sum nominalnych z realnymi i częstymi zmianami kwot przyznanych poszczególnym szkołom/nauczycielom.

O ile Achim Leschinsky i Peter M. Roeder ${ }^{9}$ odnośnie do pomorskich szkół łaski zasadniczo nie wyszli poza wcześniejsze ustalenia Ferdinanda Vollmera, o tyle Otto Gerlach ${ }^{10}$ skupił uwagę na teoretycznym ich modelu. Widział w nich wzorcowe placówki oświatowe o publicznym charakterze, co nie zawsze - dodajmy - odpowiadało pomorskiej rzeczywistości. Badacze zgodnie też stwierdzają, że szkoły łaski były maleńką cegiełką w procesie unifikacji elementarnego szkolnictwa pruskiego, któremu dały początek.

Wielkim walorem niemieckiego powojennego piśmiennictwa o systemie oświatowym absolutnego państwa pruskiego jest jego krytycyzm, co pozwoliło na odrzucenie życzeniowej projekcji w duchu indywidualizmu pruskiego,

${ }^{8}$ W. Neugebauer, Schule und Absolutismus in Preussen. Akten zum preussischen Elementarschulwesen bis 1806, Berlin-New York 1992, s. 84-90, zwłaszcza s. 98; A. Leschinsky, P.M. Roeder, Schule im historischen Prozeß. Studien zur Geschichte der preußischen Elementarschule im 18. und 19. Jahrhundert, Hamburg 1976, s. 113 i n.; F. Vollmer, Die preußische Volksschullpolitik..., s. 241 i n.

9 A. Leschinsky, P.M. Roeder, Schule..., s. 115 i n., 509.

10 O. Gerlach, Die Idee der Nationalerziehung in der Geschichte der preußischen Volksschule, Bd. 1, Langensalza-Berlin-Leipzig 1932, s. 63, 109 i n. 
ukształtowaną przez wcześniejszych badaczy ${ }^{11}$. Wydaje się, że ta dyrektywa metodologiczna w badaniach M. Neugebauera została niekiedy nieco przejaskrawiona i nazbyt ciąży nad nią teoria dyscyplinizacji oraz usilne dążenie do ukazania w absolutyzmie wszystkiego co nieabsolutne oraz pomniejszanie tego co absolutne. Skutkiem tego jest niedocenianie inicjującej funkcji państwa w procesie reform oświatowych oraz roli domen i wysokiego aparatu biurokratycznego $\mathrm{w}$ ich wdrażaniu. Pewne jest, że rola państwa w systemie oświaty Brandenburgii i Pomorza była inna.

Należy dodać, że badania te odnośnie do Pomorza pruskiego zasadniczo oparte są na publikowanej do 1945 roku bardzo skromnej podstawie źródłowej i przez to tylko w ograniczonym stopniu pogłębiają naszą znajomość systemu szkół łaski. Niewykorzystanie - też niebogatych - źródeł przechowywanych w Archiwum Państwowym w Szczecinie oraz w Landes-Archiv Greifswald jest oczywistym ich mankamentem.

Szkolnictwo elementarne na Pomorzu Zachodnim w XVI-XVIII wieku długo pozostawało poza zainteresowaniami badaczy polskich. Gdy chodzi o szkolnictwo miejskie, to pewne nim zainteresowanie zostało wywołane przez powstające od lat siedemdziesiątych XX wieku zarysy poszczególnych ziem/powiatów, a głównie monografie miast. Regułą było, że partie odpowiedzialne za szkolnictwo wykorzystywały dotychczasowe piśmiennictwo, ale niejednokrotnie je także poszerzały i pogłębiały, jak w przypadku Szczecina ${ }^{12}$ i Słupska ${ }^{13}$. Nieporównanie pesymistycznej jawi się piśmiennictwo o szkolnictwie wiejskim w wydawanych od lat siedemdziesiątych XX wieku próbach zarysów poszczególnych ziem/powiatów, w których najczęściej zajmowało ono marginalne miejsce i chronologicznie obejmowało XIX-XX wiek ${ }^{14}$. Problematyki szkół wiejskich na

\footnotetext{
${ }^{11}$ Nie dotyczy P. Schwartza i F. Vollmera.

${ }^{12}$ Dzieje Szczecina, Wiek X-1805, red. G. Labuda, Warszawa-Poznań 1987; B. Wachowiak, Szczecin w okresie przewagi państwa feudalnego 1478-1713, w: Dzieje Szczecina, Wiek X-1805..., s. 263 i n., 355 i n., 433-436; J. Wiśniewski, Poczatki układu kapitalistycznego 1713-1805, w: Dzieje Szczecina, Wiek X-1805..., s. 540-546, 676-684.

${ }^{13}$ Historia Stupska, red. S. Gierszewskiego, Poznań 1981; B. Wachowiak, W zjednoczonym Księstwie Pomorskim (1478-1648), w: Dzieje Szczecina, Wiek X-1805..., s. 176-179; Z. Szultka, W państwie brandenbursko-pruskim (1648-1806), w: Dzieje Szczecina, t. II, red. G. Labuda, Warszawa-Poznań 1985, s. 244 i n.

${ }^{14}$ Dzieje ziemi bytowskiej, red. S. Gierszewski, Poznań 1972, s. 203 i n.; Dzieje ziemi drawskiej, red. T. Gasztold, Poznań 1972, s. 118-120.
} 
wybranych obszarach dotyczyły też niektóre publikacje o przemianach etniczno-językowych ${ }^{15}$ lub stosunków kościelnych ${ }^{16}$.

Na uwagę i pozytywną ocenę zasługuje niewątpliwie prezentacja szkolnictwa wiejskiego w tomie II Historii Pomorza pod redakcją Gerarda Labudy, część $\mathrm{I}^{17}$, rozpatrywanego łącznie z kulturą i sztuką oraz stosunkami etnicznymi. Bogdan Wachowiak w części I - Próby scentralizowania państwa pomorskiego za Bogusława X i jego następców, w podrozdziale Szkolnictwo zachodniopomorskie $w$ okresie Odrodzenia ${ }^{18}$ zarysowal dzieje szkolnictwa pomorskiego przed reformacją, ukazał proces wypracowywania programu szkolnego, w tym wiejskiego, przez zwolenników reformacji przed sejmem w Trzebiatowie, kiedy postanowiono, że: „Po wsiach sztuki czytania i pisania oraz nauki wiary mieli uczyć kościelni” (s. 858), co znalazło wyraz w Ordynacji Kościelnej z 1535 roku oraz trudnościach w jej wdrożeniu w życie. Odnośnie do szkół wiejskich stwierdzono: „Nie posiadamy natomiast danych stwierdzających istnienie w miastach szkół dla dziewcząt oraz o funkcjonowaniu szkół wiejskich" (s. 859). Podstawa prawna rozwoju szkolnictwa i jej realizacja są treścią podrozdziału: Rozbudowa szkolnictwa na Pomorzu Zachodnim (1571-1637-1648), którego konkluzja brzmi: „Rozwój szkolnictwa na wsi pomorskiej był w omawianym okresie jeszcze bardzo słabo zaawansowany. Prowadzili je najczęściej pastorzy lub kościelni, a program nauki poza nauką katechizmu obejmował zapewne tylko początki pisania i czytania" (s. 1018).

Część 3 tomu II Historii Pomorza, obejmująca lata 1648-1815, przedziela rok $1720^{19}$. W podrozdziale: Rozwój szkolnictwa wiejskiego na Pomorzu brandenbursko-pruskim do początków XVIII wieku (s. 447-450), w znacznym stopniu opartym na materiałach empirycznych, Zygmunt Szultka stworzył nowy obraz szkolnictwa wiejskiego na Pomorzu brandenbursko-pruskim w stosunku do prezentowanego dotąd w literaturze. Na ile jest on prawdziwy pokażą prowadzone badania. Przeję-

${ }^{15}$ K. Ślaski, Przemiany etniczne na Pomorzu Zachodnim w rozwoju dziejowym, Poznań 1954, s. 174 i n.; Z. Szultka, Główne linie rozwoju ludności kaszubskiej do roku 1945, w: Pomorze Zachodnie w tysiacleciu, red. P. Bartnik, K. Kozłowski, Szczecin 2000, s. 185 i n.

${ }^{16}$ Z. Szultka, Język polski w Kościele ewangelicko-augsburskim na Pomorzu Zachodnim od XVI do XIX wieku, Wrocław 1991, s. 146 i n., 207 i n.

${ }^{17}$ Historia Pomorza. Tom II do roku 1815, red. i wstęp G. Labuda. Część I (1464/66-1648/57), oprac. M. Biskup, M. Bogucka, A. Mączak, B. Wachowiak, Poznań 1976.

${ }^{18}$ B. Wachowiak, Szkolnictwo zachodniopomorskie w okresie Odrodzenia, w: Historia Pomorza. Tom II..., s. 855-860.

${ }^{19}$ Historia Pomorza. Tom II..., Część 3: Pomorze Zachodnie w latach 1648-1815, oprac. Z. Szultka, H. Lesiński, współudział D. Łukasiewicz, A. Wielopolski, Poznań 2003. 
cie przez Prusy delty Odry ze Szczecinem w 1720 roku stanowiło cezurę w dziejach Pomorza pruskiego i szwedzkiego, ale nie szkolnictwa wiejskiego - to główna teza rozdziału - Wzrost roli państwa w przemianach systemu oświaty Pomorza pruskiego w XVIII wieku (1720-1815) pióra Dariusza Łukasiewicza i Zygmunta Szultki ${ }^{20}$. Jakkolwiek powszechny obowiązek szkolny do końca tego stulecia pozostawał w sferze marzeń, nie ulega jednak wątpliwości, że szkolnictwo wiejskie na Pomorzu pruskim na początku i na końcu XVIII wieku dzieliła przepaść, głównie za sprawą wiodącej roli państwa w jego reformach i przemianach.

Dla D. Łukasiewicza badania te stały się impulsem do poszerzonych zainteresowań szkolnictwem pomorskim w drugiej połowie XVII i w XVIII w., głównie miejskim, które zaowocowały szeregiem publikacji. Ich mankamentem jest nieostrość rzeczowa i chronologiczna. Jeszcze ważniejsze jest, że na ich podstawie nie można określić dynamiki przemian szkolnictwa, głównie wiejskiego oraz czynników ją kształtujących ${ }^{21}$.

W ostatnich latach bibliografia nowożytnego szkolnictwa pomorskiego wzbogaciła się o kilka drobnych artykułów Sylwii Wesołowskiej o odtwórczym charakterze ${ }^{22}$. Wspomnieć też należy spostrzeżenia Kazimierza Kallaura o szkolnictwie wiejskim powiatu słupskiego w drugiej połowie XVIII wieku ${ }^{23}$.

Genezę i okoliczności powołania na Pomorzu pruskim szkół łaski przedstawili F. Vollmer i M. Wehrmann, którzy zwrócili uwagę, że wyniesione przez Fryderyka II w czasie wojny siedmioletniej przeświadczenie o większej waleczności i przydatności na polu walki żołnierza chociaż trochę oświeconego nad nieokrzesanym prostym szeregowcem, i zaraz po ustaniu działań wojennych

\footnotetext{
${ }^{20}$ D. Łukasiewicz, Z. Szultka, Wzrost roli państwa w przemianach systemu oświaty Pomorza pruskiego w XVIII wieku, w: Historia Pomorza. Tom II..., Część 3..., s. 875-896.

${ }^{21}$ D. Łukasiewicz, Państwo brandenbursko-pruskie wobec szkolnictwa na Pomorzu Zachodnim w latach 1648-1806, w: Szlachta - społeczeństwo - państwo między Warmia a Rugia w XVIII-XX wieku, red. M. Jaroszewicz, W. Stępiński, Szczecin 1998, s. 83-92; tenże, Pruska szkoła na Pomorzu Zachodnim w XVII-XVIII w. Podstawy materialne. Programy nauczania. Nauczyciele, „Przegląd Historyczny” 1996, nr 1 (87), s. 1031; tenże, Reformy szkolnictwa na Pomorzu Zachodnim w XVIII w., „Przegląd Zachodni” 1996, nr 3 (87), s. 515-530.
}

${ }^{22} \mathrm{~S}$. Wesołowska, Materiały do dziejów szkolnictwa elementarnego w powiecie gryfickim do połowy XIX w., w: Trzebiatów - spotkania pomorskie - 2005 r., red. J. Kochanowska, Wołczkowo 2006, s. 81-91; taż, Szkolnictwo wiejskie na Pomorzu w XVIII wieku - przyczynek do dziejów, w: Dzieje wsi pomorskiej: III Międzynarodowa Konferencja Naukowa, red. R. Gaziński, A. Chludziński, Dygowo-Szczecin 2004, s. 27-36.

${ }^{23}$ K. Kallaur, Szkolnictwo elementarne $w$ powiecie stupskim $w$ drugiej połowie XVII wieku, w: XII Konferencja Kaszubsko-Pomorska. Szkolnictwo i oświata na Pomorzu (XVI-XX w.), red. Z. Romanow, Słupsk 2013, s. 33-47. 
(12.08.1763 r.) wydał generalny regulamin szkolny, obowiązujący w całym kraju, który miał mu zapewnić w przyszłych wojnach bitnych żołnierzy, zwłaszcza podoficerów. Regulamin spotkał się z niechęcią i oporem w całym państwie, największym na Pomorzu, głównie wschodniej jego części, gdyż tutaj szkolnictwo elementarne na wsi było najsłabiej rozwinięte. Jednak Konsystorze w Szczecinie i Koszalinie podjęły działania mające na celu jak najpełniejszą jego realizację. W tym m.in. celu sporządziły dokładną ewidencję wszystkich szkół miejskich i wiejskich, co pozwoliło na krytyczną i wnikliwą ocenę rzeczywistego stanu szkolnictwa pomorskiego, w tym również jego braków, która spotkała się z krytyczną oceną króla ${ }^{24}$.

Wysiłki pomorskich władz dostrzegł i docenił jeden z najlepszych ministrów Fryderyka II - Karl A. v. Zedlitz-Leipe (1731-1793) stojący od 18 stycznia 1771 roku na czele Departamentu Duchownego, właściwego dla spraw szeroko pojętego szkolnictwa. Ponieważ jednym z najważniejszych powodów słabości oświaty na Pomorzu był brak środków finansowych, dlatego wykorzystał on ideę ówczesnego superministra do spraw Pomorza i Nowej Marchii Franza B. Schönberg von Brenckenhoffa (1723-1780), który przedłożył królowi pomysł utworzenia specjalnego funduszu szkolnego, pochodzącego z odsetków od środków finansowych przyznanych przez króla dla szlachty pomorskiej i nowomarchijskiej na oddłużenie oraz odbudowę jej dóbr ziemskich po zniszczeniach wojny siedmioletniej. Na początku 1767 roku zadłużenie dóbr szlacheckich Pomorza pruskiego kształtowało się w granicach 4055000 talarów i stanowiło około 77,9\% ich wartości. W latach 1763-1771 pomoc finansowa i materialna dla Pomorza wynosiła kilka milionów talarów, ale trafiała głównie do domen. Całością spraw kierował v. Brenckenhoff. Od 1772 roku królewska pomoc kredytowa uległa reorganizacji; została skierowana prawie w całości do szlachty i związana z melioracjami - regulacją lokalnych układów wodnych oraz akcją kolonizacyjną, wreszcie przybrała planowy charakter. Kredyty były udzielane na bardzo korzystnych warunkach, bo Fryderyk II traktował fundusz melioracyjny jako formę rekompensaty za krew przelaną przez szlachtę pomorską w minionej wojnie. W 1772 roku fundusz melioracyjny wynosił ponad 287000 talarów, w 1773 roku - 200 000, zaś w 1774 roku - 54500 talarów, które - w intencji króla - miały trafić do szlachty najbardziej zadłużonej i doświadczonej największymi nieszczęściami. W praktyce zaś

\footnotetext{
${ }^{24}$ F. Vollmer, Die preußische Volksschulpolitik..., s. 145 i n.; M. Wehrmann, Vom Schulwesen im Neustettiner Kreise im Jahre 1773, Unsesrer Heimat-Museum 2, 1928, s. 2 n.
} 
uzyskała je pomorska elita biurokratyczno-wojskowa - ministrowie, dyrektorzy, generałowie i pułkownicy. Minister spraw zagranicznych Prus - Heinrich von Podewils uzyskał 19300 talarów, jego brat, hrabia E.L. v. Podewils - 7600, prałat von Blankenburg - 18 400, dyrektor szczecińskiej Kamery Wojenno-Skarbowej C.B. von Below - 15500 talarów. Zbliżoną kwotę otrzymał generał Friedrich W. von Grumbkow - syn prezydenta Pomorza pruskiego i ministra Philippa O. v. Grumbkowa ${ }^{25}$. Od 1775 roku rozdział środków uległ zmianie. Po trzech latach kredytobiorcy powinni spłacać $2 \%$ odsetków od uzyskanych kredytów, ale na prośbę szlachty Fryderyk II prolongował termin spłaty do 5 lat, licząc od zakończenia inwestycji, realizowanej według projektu i pod nadzorem państwa. $\mathrm{Na}$ fundusz nauczycielski/szkolny składać się miały jednak tylko $2 \%$ odsetków od funduszu melioracyjnego za lata 1773-1774, czyli od kwoty 254500 talarów, pomniejszonej nieco przez króla, który zwolnił niektórych kredytobiorców od płacenia odsetków. W 1777 roku dlatego do kasy szkolnej wpłynęły 4652 talary, zaś w 1781/1782 roku - 4972 talary, z czego nauczycielom szkół łaski przypadło 4628 talarów. W następnych latach do dyspozycji Konsystorza pozostawała coraz wyższa suma, w 1784/1785 roku - 5118 talarów, w 1785/1786 roku - 5219 talarów, w 1804/1805 roku - 5476 talarów. Wynikało to stąd, że od 1777 roku część odsetek ulokowano w banku, potem w papierach Pomorskiego Ziemstwa Kredytowego. Formalnie wśród nauczycieli aż do 1806 roku rozdzielono 4652 talary, 6 groszy i 5 fenigów. Ponieważ wynagrodzenie nauczyciela szkoły łaski na Pomorzu wynosić miało 80 talarów, państwowy fundusz szkolny - według pierwotnych założeń - mógł być podstawą utrzymania 58 szkół. Występujące nadwyżki przeznaczano na inne cele, mianowicie od 1777 roku 320 talarów rocznie otrzymywało sześć pensjonariuszek słupskiego zakładu panieńskiego, powstałego na gruncie zniesionego klasztoru norbertanek, od 1784 czy 1785 roku wypłacano 216 talarów rocznie sześciu preparandystom seminarium nauczycielskiego przy szkole na Łasztowni w Szczecinie oraz 125 talarów drugiemu nauczycielowi seminarium, 50 talarów otrzymywał rendant kasy szkolnej; z funduszu szkolnego pokrywano jeszcze inne niższe stałe lub okresowe wydatki oraz - zdaje się - budownictwo szkolne ${ }^{26}$. Widać, że odsetki z pomorskiego funduszu melioracyjnego

${ }^{25}$ Z. Szultka, Pomorze Zachodnie prowincja państwa pruskiego (1720-1815), w: Historia Pomorza, t. III, cz. 1, s. 567-579, tamże literatura.

${ }^{26}$ Archiwum Państwowe w Szczecinie (dalej AP Szczecin), Konsystorz Ewangelicki w Szczecinie (dalej Konsystorz), 472, f. 1 n.; 456, f. 1-2, 13; 461, f. 101 n.; 462, f. 9-10, 57-58; 463, f. 2-3, 202-203; 409, f. 351-352; F. Vollmer, Die preußische Volksschulpolitik..., s. 145 i n., 160, 166 i n. 
za lata 1773-1774 nie w całości trafiały do nauczycieli/szkół łaski. Szacunkowo około 10\% środków przeznaczono na cele niezwiązane bezpośrednio z wiejskim szkolnictwem elementarnym.

Sprawom finansowym poświęcono tak wiele miejsca $\mathrm{z}$ dwóch powodów, bo wiążą się one z szerszym problemem - programem reform wiejskich szkół elementarnych w całym państwie pruskim pod koniec XVIII wieku oraz rolą w nim państwa. Drugim powodem jest nieostra ich prezentacja w najnowszej literaturze niemieckiej. Do sprawy tej wrócimy niżej, tu pragniemy się ograniczyć do stwierdzenia, że w literaturze tej zgodnie prezentowano pogląd, iż minister von Zedlitz do szkół łaski przywiązywał bardzo dużą wagę, bo miały one stanowić istotę jego programu reform elementarnych szkół wiejskich w całym kraju. Jego reformatorskie działanie odnośnie do szkolnictwa wiejskiego ograniczały się właśnie do szkół łaski; inne szkoły pozostawały poza jego zainteresowaniami, co wynikało ze świadomego działania, m.in. z tego, że państwo pruskie przeznaczyło na rzecz szkolnictwa wiejskiego tylko te środki, które przypaść miały szkołom łaski. Przez to szkoły łaski stały się niejako szkołami państwowymi i jako takie miały być niekwestionowanym dowodem słuszności państwowej reformy szkolnej. Szkoły łaski miały być modelowymi placówkami oświatowymi; wzorcem organizacyjnym, finansowym, programowym i metodycznym dla wszystkich pozostałych szkół wiejskich, tj. dla ich patronów, inspektorów szkolnych i nauczycieli, a także całych społeczności wiejskich ${ }^{27}$.

Funkcja modelowa szkół łaski jako dzieła państwa pozostawała w ścisłym związku z ich drugim celem - unifikacyjnym i integracyjnym (dotyczy Prus Zachodnich). System szkół łaski rozwinięty został przez państwo pruskie w trzech terytoriach (prowincjach): od 1770 roku w Marchii Elektorskiej, gdzie doszło do ukształtowania się 58 takich placówek z pensją 120 talarów, od 1777 roku na Pomorzu pruskim, na obszarze którego powołano 49 takich szkół z pensją nauczyciela 80 talarów (formalnie) oraz od 1776 roku w Prusach Zachodnich, gdzie nauczyciel otrzymać miał pensję 60 talarów i całe szkolnictwo miało być oparte na systemie szkół łaski. Ponieważ w Marchii Brandenburskiej stanowiły one około 4\%, a na Pomorzu około 6\% ogółu szkół wiejskich, więc funkcji unifikacyjnej

${ }^{27}$ M. Heinemann, Schule im Vorfeld der Verwaltung. Die Entwicklung der preußischen Unterrichtsverwaldung von 1771-1800, Göttingen 1974, s. 202-203; W. Neugebauer, Das Bildungswesen in Preußen seit des Mitte des 17. Jahrhunderts, w: Handbuch der Preussischen Geschichte. Handbuch der Preussischen Geschichte, Bd. II, red. von O. Büsch, Berlin-New York 1992, s. 658; tenże, Schule und Absolutismus..., nr 102, s. 410 i n. 
w skali prowincji, a tym bardziej kraju, spełnić nie mogły. W Prusach Zachodnich zaprowadzenie szkolnictwa niemieckiego, w ocenie najwyższych przedstawicieli pruskich władz oświatowych z końca XVIII wieku, zakończyło się całkowitym niepowodzeniem $\mathrm{z}$ wielu powodów, $\mathrm{z}$ których mniej więcej połowa leżała po stronie władz pruskich, a połowa wynikała z postawy ludności polskiej. O spełnieniu oczekiwanych wobec nich zadań mowy być nie może ${ }^{28}$. Przez pryzmat zarysowanych celów i funkcji szkół łaski w państwie pruskim rozpatrywać będziemy ich powołanie i funkcjonowanie na Pomorzu pruskim.

Początek realizacji idei szkół łaski na Pomorzu dał reskrypt ministra v. Zedlitza z 20 stycznia 1773 roku informujący dyrektora szczecińskiego Konsystorza, czyli najwyższego organu administracji szkolnej w szczecińskim okręgu kameralnym, Gottlieba F. Herra o niezadowoleniu króla ze złego kształcenia/uczenia dzieci na Pomorzu, głównie wiejskich. W celu poprawy istniejącej sytuacji król wyasygnował określoną kwotę dla nauczycieli około 40 miejscowości wybranego, zamkniętego terenu. Proponował, aby były to miejscowości położone wzdłuż trasy przejazdu króla na coroczne manewry wojskowe w okolicy Stargardu. Zobowiązał dyrektora do sporządzenia wykazu proponowanych miejscowości, których kwalifikowani nauczyciele otrzymywaliby pensje ze specjalnego funduszu nauczycielskiego/szkolnego w wysokości 100 talarów. Proponował sprowadzenie nauczycieli z Saksonii, zwolnienie rodziców z opłaty szkolnej oraz premiowanie zdolnych dzieci i nauczycieli. Szkoły te miały pozostać pod ścisłą kontrolą władz oświatowych, aby w ten sposób zapewnić pełną realizację wytycznych. W mających powstać szkołach miały obowiązywać nowe podręczniki ${ }^{29}$, nauka miała być bezpłatna, egzaminy uczniowie zdawaliby co pół roku, zaś wyróżniający się nauczyciele mieli być premiowani ${ }^{30}$.

Minister określił również warunki uzyskania środków ze szkolnego funduszu łaski przez wnioskodawców, którzy byli zobowiązani przedstawić dotychczasową szkołę i nauczyciela lub powody ich braku, stosunek patrona do szkoły,

\footnotetext{
${ }^{28}$ F. Wienecke, Die Landgnadenschulen der Kurmark, w: Schulblatt für die Provinz Brandenburg, 1905, Bd. 70, s. 254 i n.; F. Vollmer, Die preußische Schulpolitik..., s. 140, 145 i n.; P. Schwartz, Die Schulen der Provinz Westpreußen, s. 77-78; W. Neugebauer, Das Bildungswesen..., s. 631-632, 658-659; A. Leschinsky, P.M. Roeder, Schule..., s. 117-115.

${ }^{29}$ Chodziło prawdopodobnie o F.E. Rochow, Versuch eines Schul-Buchs für Kinder der Land-Leute oder zum Gebrauch in Dorf-Schulen, Berlin 1772; tenże, Der Kinderfreund, ein Lesebuch zum Gebrauch in Landschulen, Berlin 1776.
}

${ }^{30}$ AP Szczecin, Konsystorz, 440, f. 1-2. 
liczbę dzieci planowanej szkoły oraz pastora i prepozyta jako organów nadzoru szkolnego ${ }^{31}$.

Minister zapoczątkowując budowę szkół łaski, ze zrozumiałych względów, główny akcent w swym wystąpieniu położył na sprawy organizacyjne. Na szczególną jednak uwagę zasługuje jego końcowy fragment, w którym wypowiedział się w sprawie treści i metod nauczania, podkreślając, że należy zadbać o nauczycieli, którzy będą zdolni zrezygnować z pamięciowego systemu nauczania na rzecz racjonalnego rozumowania. Jeszcze ważniejsze znaczenie miało zdanie: „Dobre urządzenie szkolnictwa i jego rozwijanie ma wielkie znaczenie nie tylko dla całych przyszłych pokoleń, ale jest również niezawodnym środkiem zdobycia łaski króla" ${ }^{32}$. Wynika z tego, że: 1) szkoły łaski miały być istotą długofalowej reformy szkolnictwa elementarnego na Pomorzu pruskim; 2) jej wdrożenie było wielką troską króla pruskiego oraz ministra v. Zedlitza, bo miała ona być korzystna dla wielu pokoleń; 3) głównym założeniem programowym miało być odejście od dotychczasowego pamięciowego systemu nauczania na rzecz nauczania racjonalnego, dostosowanego do możliwości recepcyjnych dzieci i pomocnego w zrozumieniu rzeczywistości życiowej; 4) w tym celu należało wprowadzić nowe podręczniki; 5) wdrożenie całego systemu miało być oparte na nowym, kwalifikowanym i lepiej wynagradzanym nauczycielu, który był przysłowiową „twardą skałą” całego systemu. Od ukształtowania nowego nauczyciela, zdolnego zorganizować nauczanie na nowych racjonalnych zasadach, zależało nie tylko powodzenie systemu szkół łaski, ale całego pomorskiego szkolnictwa elementarnego miast i wsi, bo szkoły łaski miały być modelowymi placówkami wychowawczo-oświatowymi na wsi Pomorza pruskiego. Ubiegając nieco fakty należy dodać, że od 1773 roku reforma całego elementarnego szkolnictwa wiejskiego ograniczała się do szkół łaski, pozostawiając inne szkoły daleko poza zainteresowaniami władz administracji szkolnej. Należy jeszcze podkreślić, że v. Zedlitz w imieniu państwa zadeklarował opłacenie tylko 40 nauczycieli szkół łaski, co było kroplą w morzu potrzeb, jednak na wyższą kwotę nie miał zgody króla. Potrzeby materialne i finansowe szkół wiejskich pokrywała ludność wiejska, tu i tam wspierana przez gorliwego pastora oraz pobożnego i światłego patrona.

Manfred Heinemann zwrócił uwagę, że minister v. Zedlitz - dodajmy, a za nim władze Pomorza pruskiego - tego kierunku reformy szkół elementarnych

\footnotetext{
${ }^{31}$ Tamże, s. 2-3.

32 Tamże, s. 3.
} 
na wsi nie zmienił nawet po 1779 roku, czyli jego projektu reformy szkolnictwa pruskiego, z dwóch powodów, mianowicie, system szkół łaski miał potwierdzić słuszność jego reformy i funkcjonalność tych szkół oraz - państwo pruskie ograniczyło się do finansowania lub finansowego wspierania bardzo ograniczonego kilkuprocentowego odsetka kwalifikowanych nauczycieli i na więcej nie przeznaczyło środków finansowych. W koncepcji v. Zedlitza szkoły łaski miały być dobrym przykładem i skłonić patronów, pastorów i nauczycieli do ich naśladowania i dobrowolnego wdrażania reformy pozostałych szkół, co nastąpiło dopiero w początkach XIX wieku, ale wcale nie dobrowolnie ${ }^{33}$.

Dyrektor Herr polecenia ministra starał się jak najdokładniej wykonać - od 10 do 28 maja 1773 roku odbył podróż - inspekcję wzdłuż tras przejazdu króla po Pomorzu, mianowicie z Berlina do Starogardu, ze Starogardu do Szczecina i ze Starogardu przez Szczecinek do Kwidzyna. Detalicznie opisał 75 miejscowości i zaproponował urządzenie szkół finansowanych z funduszu nauczycielskiego/ szkolnego w 52 z nich (40 we wsiach domenialnych, 4 we wsiach miejskich, 4 szlacheckich, 4 - z mieszanymi właścicielami oraz w Czaplinku, Barwicach) ${ }^{34}$. Najwięcej w domenach Drahim (12) i Kołbacz (8). Propozycja ta miała znaczenie dla dalszego biegu sprawy, bo punktem wyjścia stała się liczba nie 40 lecz 50 szkół, czego konsekwencją był spadek maksymalnego wynagrodzenia nauczyciela ze 100 do 80 talarów.

Dla naszych rozważań ważniejszy jest stosunek Herra do pozostałych zagadnień przedstawionych przez v. Zedlitza, gdyż rzucają one światło na stan szkolnictwa na Pomorzu pruskim. Zwrócił uwagę na fatalny stan izb lekcyjnych w mieszkaniach nauczycieli, co bardzo niekorzystnie rzutowało na zdrowie uczących się dzieci. Częściowo poparł ideę bezpłatnej nauki, bo ówczesna opłata szkolna była jednym z głównych powodów upadku szkół, zwłaszcza letnich, gdyż rodzice nie byli w stanie - z powodu biedy - jej uiścić. Proponował utrzymanie opłaty w wysokości 6 groszy od dziecka w skali rocznej oraz utworzenie funduszu na zakup książek dla biednych dzieci. Gorąco poparł koncepcję zmiany systemu nauczania z pamięciowego na „pojęciowe” i zaprowadzenie proponowanych przez ministra podręczników, ale od razu podkreślił, że te zmiany wymagają nauczycieli z umiejętnością ,pojęciowego" (Begriff) nauczania, takich zaś rzadko można było znaleźć, bo większość nauczycieli nie umiała pisać i liczyć. Problem ten można było

${ }^{33}$ M. Heinemann, Schule im Vorfeld..., s. 171, 202-203.

${ }^{34}$ AP Szczecin, Konsystorz, 440, f. 6 i n., 67-72. 
rozwiązać tylko przez kształcenie nauczycieli w seminariach, bo kler też nie był przygotowany i zaproponował wprowadzenie obowiązku 6-letniej pracy w szkole dla kandydatów na pastorów. Do tej propozycji w 1800 roku powrócił Zarząd Pomorza. Krytycznie oceniał pedagogiczne umiejętności kleru jako nadzoru w szkołach. Jeszcze krytyczniej wypowiedział się w sprawie sprowadzania na Pomorze nauczycieli z Saksonii, bo napływaliby najgorsi, a otrzymaliby wynagrodzenie 100 talarów, a ponadto należało wziąć pod uwagę różnice językowe i kulturowe między Saksończykami i Pomorzanami ${ }^{35}$. Był też przeciwny półrocznym egzaminom szkolnym, dopuszczał zaś egzaminy roczne połączone z wizytacjami szkół i kościołów przez proboszczów i prepozytów. Poparł natomiast ideę premiowania uczniów i nauczycieli, nawet określił kryteria i wysokość nagrody. Nauczyciele stosujący metody Friedricha Eberhardta Rochowa mieli być premiowani 10 talarami ${ }^{36}$.

Od 1773 roku Konsystorz Ewangelicki w Szczecinie, któremu podlegały wszystkie sprawy związane z funduszem szkolnym, utrzymywał stałą korespondencję z Berlinem dotyczącą szkół łaski. W celu ich wdrożenia w październiku tego roku zażądał od superintendentów pełnego wykazu szkół. Z fragmentarycznie zachowanych sprawozdań wynikało, że stan szkolnictwa wiejskiego był doprawdy krytyczny i uświadomił władzom pomorskim, że realizacja idei szkół łaski napotka na duże trudności. Zgodnie z instrukcją von Zedlitza rozdział funduszu szkolnego był właściwością Konsystorza - jego dyrektora G. Herra, zobowiązanego do konsultowania wszystkich najważniejszych spraw z generalnym superintendentem Pomorza Friedrichem Ch. Göring'em (1775-1791) oraz von Brenckenhoffem, którego - jak zobaczymy - głos miał największe znaczenie. W praktyce sprawy szkół łaski prowadził sekretarz Konsystorza Hoeckendorff, który pozostawał też w stałym kontakcie z kasą Kamery Wojenno-Służbowej w Szczecinie ${ }^{37}$.

Niedostatki w stanie badań i fragmentaryczność przebadanych źródeł sprawiają, że początki funkcjonowania szkół łaski na Pomorzu są bardzo niejasne. Ponieważ środki funduszu szkolnego pozostawały do dyspozycji Konsystorza od Trójcy św. (25 maja) 1777 r. Konsystorz pierwszego rozdziału środków dokonał już pod koniec 1776 r. Trzeba dodać, że wnioski o ich przydział wpływały już

\footnotetext{
${ }^{35}$ M. Heinemann (Schule im Vorfeld..., s. 144) pisze, że v. Zedlitz, w przeciwieństwie do króla, nie był zwolennikiem importowanych nauczycieli.

36 Tamże, s. 16-19.

${ }^{37}$ AP Szczecin, Konsystorz, 456, f. 1-3, 13 i n.; M. Wehrmann, Vom Schulwesen im Kreise Greifenberg zur Zeit Friedrichs des Großen, „Greifenberger Kreiskalander“' 1925, s. 92-93; tenże, Vom Schulwesen im Neustettiner Kreise..., s. 5.
} 
od początku 1775 roku, głównie od szlachty i z miast. Szkolny fundusz łaski wywołał więc duże zainteresowanie szkolnictwem i przez to przed Konsystorzem stanęło bardzo trudne zadanie rozdziału środków funduszu szkolnego. Na początku 1776 roku Fryderyk II za sprawą v. Brenckenhoffa rozkazał, że pierwszeństwo w przydziale środków winni mieć koloniści, tj. mieszkańcy osad kolonijnych założonych w czasie rządów Fryderyka II, którym gwarantowano szkoły ze środków państwowych. Na tej podstawie koloniści usilnie domagali się szkół, chociaż Konsystorz miał o ich rzeczywistym stosunku do szkolnictwa jak najkrytyczniejsze zdanie ${ }^{38}$. Wspomniany rozkaz Fryderyka II zadecydował - jak zobaczymy - o charakterze pomorskiego systemu szkół łaski, gdyż stawiał w uprzywilejowanej pozycji domeny, bo do początku lat siedemdziesiątych XVIII wieku w nich prowadzono głównie kolonizację. Dzięki rozkazowi pojawiły się również relatywnie duże możliwości ubiegania się o środki z funduszu łaski dla najzamożniejszej szlachty, związanej z pruskim aparatem biurokratycznym i generalicją, które w latach 1772-1774 zaciągnęły duże pożyczki z funduszu melioracyjnego na modernizację swych dóbr ${ }^{39}$.

25 listopada 1776 roku Konsystorz przesłał do Berlina, celem zatwierdzenia, wykaz 47 nauczycieli/szkół wiejskich w domenach i dobrach miejskich (ale koloniach), którzy od lata 1777 roku mieli otrzymywać pensję 80 talarów rocznie, uzgodniony z miejscową Kamerą Wojenno-Skarbową, nadwornym kaznodzieją reformowanym Hahnem ze Starogardu oraz aprobowany przez von Brenckenhoffa. Konsystorz ogólnie zaznaczył, że przy jego sporządzeniu brano pod uwagę opinie superintendentów, wielkość wsi, jej położenie względem sąsiednich osiedli, liczbę dzieci i inne czynniki. Zaproponował również przyznanie pensji nauczycielom z Juchowa koło Szczecinka, należącego do generała Aleksandra von Kleista, oraz z Wierszyna koło Słupska, będącego własnością von Puttkamera. Ich pensje razem wynosić miały tylko 66 talarów. W sumie wykaz obejmował 49 nauczycieli/szkół wiejskich, którzy mieli otrzymać łącznie 3826 talarów z funduszu szkolnego. W 18 z nich nie było budynków szkolnych i dlatego wypłata pensji miała nastąpić dopiero z chwilą rzeczywistego uruchomienia szkoły. W rzeczywistości więc nie można było ustalić jacy nauczyciele faktycznie od trzeciego kwartału 1777 roku otrzymywali pensje z funduszu szkolnego. Nauczyciele

${ }^{38}$ A. Detto, Die Besiedlung des Oderbruches durch Friedrich den Großen, ,Forschungen zur Brandenburgischen und Preußischen Geschichte" 1903, t. 16, s. 177 i n.

${ }^{39}$ AP Szczecin, Konsystorz, 441, 16 n.; 452, f. 16 n.; F. Vollmer, Die preußische Volksschulpolitik..., s. 166, 168-169. 
w miejscowościach, w których działały już szkoły zobowiązani byli za dotychczasowe swe dochody kupować książki i pomoce naukowe dla dzieci ${ }^{40}$.

W opinii Konsystorza z listopada 1776 roku, w miasteczkach: Banie, Barwice, Czaplinek, Dobrzany, Nowogard, Płoty i Połczyn ubóstwo mieszkańców było tak wielkie, że nie byli oni w stanie uiszczać opłaty szkolnej i dlatego ich szkółki znajdywały się w fatalnym stanie i większość miejscowych dzieci się nie uczyła. Konsystorz nie wykluczał możliwości udzielenia im pomocy z funduszu szkolnego, chociaż był świadom, że naruszałoby to otrzymane instrukcje i dlatego ujął je na oddzielnym wykazie. Minister von Zedlitz możliwość taką odrzucił pod pretekstem, że nie leżały one na trasie przejazdów króla przez Pomorze ${ }^{41}$.

Konsystorz w Szczecinie na przełomie 1776/1777 roku przesłał ministrowi v. Zedlitzowi kilka uzupełniających wykazów proponowanych szkół łaski. Ostatecznie minister przyznał 24 marca 1777 roku pensje łaski 78 nauczycielom z 76 wsi, gdyż w dwóch wsiach kolonijnych miały być dwie szkoły - luterańska i reformowana. W ten sposób rozdysponowano 4628 talarów, średnia pensja wynosić miała nie 80, lecz niespełna 60 talarów ${ }^{42}$.

Na podstawie tych materiałów nie można jednak ustalić liczby szkół uruchomionych latem 1777 roku z dwóch powodów. Nie ma żadnej pewności, że we wszystkich szkołach wiejskich, które otrzymały formalnie pensje łaski byli nauczyciele oraz budynki szkolne, czy chociażby izby lekcyjne. Na berlińskiej liście z 24 marca 1777 roku znalazło się 25 wsi (35\%), prawie wszystkie domenialne, w których brakowało budynków szkolnych, zabezpieczenia opałowego, jakiegokolwiek wyposażenia i najczęściej nauczycieli. W przypadku domen doszło do absurdu, bo przydzielono pensje nauczycielom, chociaż nie było wiadomo w jakiej szkole mieli oni uczyć („Trzesieka albo Chwalimie”, „Parsęcko albo Podgaje"). W przypadku kolonii Friedrichsthal, o której będzie mowa, przyznano nauczycielowi 40 talarów, chociaż zimą uczył on tylko troje dzieci, a latem żadnego. 80 talarów otrzymał ,inspektor gospodarczy” z Wierszyna, który doprawdy z nauczaniem dzieci w szkole nie miał wiele do czynienia. Według wykazu z 24 marca 1777 roku 24 nauczycielom/szkołom przyznano pensje 80 talarów. Najniższą pensję (19 talarów) miał otrzymywać nauczyciel z Chlebowa w domenie Kołbacz.

${ }^{40}$ AP Szczecin, Konsystorz, 440, f. 108-110.

${ }^{41}$ AP Szczecin, Konsystorz, 440, f. 109, 112 i n.; F. Vollmer, Die preußische Volksschulpolitik..., s. 174.

${ }^{42}$ AP Szczecin, Konsystorz, 456, f. 1 n.; 440, f. 112 n. 
Pięciu szkołom wsi miejskich (6,6\%) przyznano 4,7\% środków pieniężnych. Dla 18 wsi szlacheckich wskaźniki te wyniosły odpowiednio $23,7 \%$ i $19,5 \%$, zaś dla wsi domenialnych 70\% i 75,8\% ${ }^{43}$. Faworyzowanie szkół w domenach, a zwłaszcza wsi kolonialnych, głównie w domenach Kołbacz, Pyrzyce, Podlesie i Szadzko będzie tym wyraźniejsze, jeśli dodamy, że w 1782 roku stanowiły one 28,8\% samodzielnych osad wiejskich Pomorza pruskiego, szlacheckie - 63,7\% zaś miejskie $-7,5 \%{ }^{44}$. Najbardziej poszkodowana była drobna i średnia szlachta. Wyjątki wśród niej stanowili reprezentanci, którzy byli spokrewnieni z generałami czy pułkownikami lub innymi wysokimi przedstawicielami pruskiej biurokracji. Zatwierdzony 24 marca 1777 roku rozdział środków funduszu szkolnego miał wybitnie polityczny charakter i był daleki od rzeczywistości. Prędzej czy później musiał ulec korekcie.

Trudności ze znalezieniem w 1777 roku odpowiednich nauczycieli były ogromne i pragniemy je przedstawić na przykładzie synodu dobrzańskiego, którego superintendent Johann F. Eilert (1772-1798) w 1776 roku rekomendował siedmiu nauczycieli-rzemieślników, po trzech ze wsi domenialnych i szlacheckich oraz jednego z Dobrzan (formalnie tylko miasteczka, faktycznie zaś większej wsi), jako kandydatów do pensji łaski. Dwóch z nich „źle”, a jeden ,jako tako” czytał, dwóch dalszych dobrze czytało i ,jako tako" pisało, umiejętności jednego superintendent nie określił. Stwierdził, że najlepszym nauczycielem w synodzie jest krawiec Johann Hoening z Szadzka, syn miejscowego nauczyciela, który został bardzo dobrze przygotowany do zawodu, gdyż płynnie czyta, pisze i liczy ${ }^{45}$. On tylko uzyskał pensję łaski.

Wydaje się, że sieć szkolna i nauczyciele synodu dobrzańskiego, w którym w 1701 roku funkcjonowało najmniej pięć szkół ${ }^{46}$, w połowie lat siedemdziesiątych XVIII wieku mogą być uznane za typowe dla Pomorza pruskiego, chociaż struktura organizacyjna i własności tego synodu odbiegała wyraźnie od podobnych we wschodniej części Pomorza. Synod składał się z 16 parafii, w tym dwóch miejskich - dobrzańskiej i suchańskiej. Dobrzany i Suchań były jednak miastami pośrednimi, strukturą społeczno-gospodarczą i funkcjami bliższe wsi niż miastu.

43 Tamże, 457, f. 80 i n.

${ }^{44}$ L.W. Brüggemann, Ausführliche Beschreibung des gegenwärtigen Zustandes des Königl. Preussischen Herzogthums Vor- und Hinterpommern, T. II, Bd. 1, Stettin 1784, s. XCVIII.

45 AP Szczecin, Konsystorz, 472, f. 6 i n.

${ }^{46}$ G. v. Bülow, Beiträge zur Geschichte der Pommerschen Dorfschulen, „Evangelisches Monatsschrift für die Deutsche Schule" 1887, nr 8, s. 249-250. 
Wszystkie parafie tego synodu traktować będziemy dlatego jako wiejskie ${ }^{47}$. Specyfiką synodu było, że aż 13 parafii pozostawało pod patronatem królewskim, trzy zaś szlacheckim. Synod liczył 35 wsi, z czego 27 należało do państwa (77\%). Wyróżniał się również tym, że liczył 16 kościołów parafialnych i 19 filialnych. Prawie w każdej wsi znajdował się kościół. Położenie synodu i jego funkcja manewrowa oraz coroczny pobyt króla - to dalsze czynniki sprzyjające rozwojowi szkolnictwa do i po 1777 roku. Nie dziwi więc, że w latach 1779-1780 dalszych osiem jego nauczycieli/szkół otrzymało pensje łaski, ale aż sześciu z nich uczyło w bliżej nieznanych izbach, bo w tylu wsiach nie było budynków szkolnych oraz jakiegokolwiek wyposażenia szkół. Zdali oni jednak egzaminy przed konsystorialną komisją kwalifikacyjną w Szczecinie lub byli absolwentami berlińskiego seminarium nauczycielskiego ${ }^{48}$.

Istniejącą sytuację dobrze charakteryzują relacje niektórych z ośmiu interesujących nas nauczycieli. Nauczyciel Dawid Teschendorf, uczący w Odargowie od września 1775 roku, zdał egzamin w 1777 roku i odtąd uchodził za nauczyciela kwalifikowanego, ale od 1775 roku do września 1779 roku nie otrzymywał żadnej opłaty od rodziców uczonych dzieci. Martin Streseman z Sulina również zdał egzamin kwalifikacyjny i utrzymywał, że mimo tego nie otrzymywał opłaty szkolnej, bo administracja domeny Marianowo w 1778 roku zwolniła rodziców od opłaty szkolnej. Teschendorf 6 września 1779 roku prosił o pensję w wysokości 65 talarów rocznie, Stresemann zaś 80. Informacje te potwierdzili pastorzy, dodając że mieszkańcy tych wsi i Wiechowa deklarują wolę podjęcia budowy szkół według projektu słynnego szczecińskiego architekta i kartografa Davida Gilly'ego (1748-1808). Wnioskodawcy uzyskali pensje w postulowanej wysokości ${ }^{49}$.

Z powyższego widać, że w praktyce od 1777 roku pomorskie władze oświatowe prowadziły na ograniczoną skalę działania mające na celu wdrożenie systemu szkół łaski. Ogólnie jednak kryteria przyznawania pensji poszczególnym nauczycielom/miejscowościom były niejasne, a dodatkowo zaciemniała je praktyka, gdyż wiele wskazuje na to, że o przyznaniu pensji z funduszu szkolnego jakiemuś

${ }^{47}$ L.W. Brüggemann, Ausführliche Beschreibung..., T. II, Bd. 1, s. LXI-LXII; H. Moderow, Die evangelischen Geistlichen Pommerns von der Reformation bis zur Gegenwart. , T. 1. Der Regierungsbezirk Stettin, Stettin 1903, s. 257.

${ }^{48}$ AP Szczecin, Konsystorz, 547, f. 189-205; 463, f. 203 i n.

49 AP Szczecin, Konsystorz, 547, s. 189-191, 204-205; 463, f. 203; E. Henning, David Gilly (1748-1808), „Baltische Studien” 1980, nr 66, s. 81; M. Stelmach, David Gilly i jego mapa Pomorza Zachodniego z 1789 r., „Przegląd Zachodniopomorski” 1983, z. 27, s. 237 i n. 
nauczycielowi/szkole/wsi w większym stopniu decydował von Brenckenhoff niż Konsystorz. Dobrze widać to na przykładzie nauczycieli/szkół synodu słupskiego, przez który nie prowadziły trasy przejazdu króla pruskiego.

W listopadzie 1776 roku wniosek o przyznanie pensji z funduszu łaski złożył porucznik Franz J.v. Below, właściciel Machowinka i Strzelina, który w 1772 roku uzyskał 12400 talarów na modernizację swych dóbr ziemskich. Zapewniał, że w liczącym około 50 dymów Machowinku szkołę prowadzi „zdolny subiekt” - Johann G. Jeschke, którego wynagrodzenie wynosi 10 talarów. Informacje te potwierdzili pastor z Wytowna i słupski prepozyt Christian W. Haken. Dodajmy, że były one zbyt optymistyczne w stosunku do rzeczywistości ${ }^{50}$.

W tym samym czasie w imieniu niesławnego generała Wilhelma S. von Bellinga (1719-1779), właściciela Świecichowa, modernizowanego kosztem 4800 talarów, wystosował jego pełnomocnik hrabia Friedrich von Werssowitz piszący, że świecichowski nauczyciel Johann Birr uczy dzieci nie tylko katechizmu i historii biblijnej, ale również czytania i pisania, w tym kaligrafii. W nauczaniu dwóch pierwszych przedmiotów miał korzystać z podręczników, co było w tym czasie osobliwością. Nauczyciel korzystał z bezpłatnego mieszkania, opału, ogrodu, pastwiska i morgi ziemi w zamian za bezpłatną naukę jakoby wszystkich dzieci katechizmu, czytania, pisania, a nawet rachowania. Nie wszystkie te informacje były prawdziwe, chociaż zostały potwierdzone przez damneńskiego pastora i wspomnianego Hakena (1771-1791) $)^{51}$.

Pensję 80 talarów rocznie uzyskał w 1780 roku nauczyciel szkółki w Wierszynie Johann F. Müller, wsi należącej do kapitana w stanie spoczynku Franza J.U. von Puttkamera (1746-1823), który w 1773 roku uzyskał 7000 talarów z funduszu melioracyjnego na poprawę stanu gospodarczego swej drugiej wsi - Wiatrołom. W Wierszynie od 1776 roku funkcjonowała szkółka zimowa, licząca 27 dzieci, głównie za sprawą kołczygłowskiego pastora, który wynagradzał nauczyciela 4 talarami rocznie. Patron wsi - von Puttkamer, nie miał zrozumienia dla jej potrzeb, chociaż uchodził za człowieka „oświeconego”. Ponadto należał do ekskluzywnego zakonu joannitów. Szkółka letnia nie doszła do skutku, bo latem dzieci musiały paść bydło lub podejmować pracę zarobkową. Wizytujący szkółkę superintendent Haken (3.06.1779 r.) stwierdził, że niektóre dzieci wykazały się

${ }^{50}$ AP Szczecin, Konsystorz, 456, f. 135 i n., s. 261.

${ }^{51}$ Tamże, f. 151-156; 458, f . 90-92; R. Klempin, G. Kratz, Matrikeln und Verzeichnisse der pommerschen Ritterschaft vom XIV bis in das XIX Jahrhundert, Berlin 1863, s. 425; L.W. Brüggemann, Ausführliche Beschreibung..., T. II, Bd. III, s. 972, 1003-1004. 
nie tylko dobrą znajomością katechizmu, ale również pisania i poparł wniosek von Puttkamera o przyznanie pensji z funduszu łaski nauczycielowi Müllerowi ${ }^{52}$. Po roku opinie Hakena będą krańcowe inne, tzn. prawdziwe.

Bardziej złożona jest sprawa początków czwartej w synodzie słupskim pensji/ szkoły łaski w Gałęźni Małej, liczącej około 50 dymów, której posesor Friedrich J.G.E. von Zitzewitz (1746-1800) w 1772 roku uzyskał 11 tys. talarów na jej modernizację. Za pozyskane środki zbudował nowy folwark, owczarnię i kolonię Friedrichsthal, złożoną z ośmiu chłopów, siedmiu robotników leśnych i młyna. We wsi nie było szkoły i von Zitzewitz planował ją założyć w kolonii. Przeciwny tej lokalizacji był superintendent Haken, który radził Konsystorzowi, aby przyznał środki łaski na rzecz mającej powstać szkoły, ale w Gałęźni Małej, gdzie znajdowała się nowa dwuizbowa chałupa z komorą. Budowski proboszcz - Johann Homann pisał, że w istniejących od niedawna szkołach w Gałęźni Wielkiej i Małej uczy jeden nauczyciel - trzy dni w tygodniu w każdej z nich. Znacznie więcej starszych dzieci chodziło do szkoły w Gałęźni Wielkiej niż małych w Gałęźni Małej i bywało, że w izbie lekcyjnej w Gałęźni Wielkiej - pozbawionej ławek i stołów - niektóre dzieci „pół- lub całkowicie nieprzytomne upadały na ziemię”. Ponadto miał bardzo krytyczną opinię o kolonistach. Mimo tego von Zitzewitz zdołał doprowadzić do uruchomienia szkoły łaski w kolonii, w której uczył nauczyciel Retzlaff, otrzymujący w 1778 roku pensję 40 talarów. W kolonii miało być jednak tylko siedmioro dzieci w wieku szkolnym, które nawet w marcu nie przychodziły do szkoły. Kiedy do pastora Homanna doszły „,smutne pogłoski o ciężkich grzechach” Retzlaffa, który nie był kwalifikowanym nauczycielem, los i jego, i szkoły był przesądzony. Szkołę przeniesiono do Gałęźni Małej, zaś nowym nauczycielem został dotychczasowy nauczyciel w tej wsi Gottfried Mielcke, który nie zdał egzaminu kwalifikacyjnego w Szczecinie. Zastąpił go w następnym roku Radatz, który zdał egzamin, otrzymał pensję 80 talarów, ale uczył najwyżej trzy lata. Szkoła w Gałęźni Małej utraciła statut szkoły łaski, przypuszczalnie z powodu niskiej frekwencji dzieci53. Proboszcz i nauczyciel nie byli w stanie zmusić kaszubskich rodziców do posyłania dzieci latem do szkoły.

${ }^{52}$ AP Szczecin, Konsystorz, 547, b.f.; 453, f. 86; 456, f. 168; 457, f. 73, 80-81; L.W. Brüggemann. Ausführliche Beschreibung..., T. II, Bd. 2, s. 810-811; F. Tribbensee, Schulwesen, w: Der Kreis Rummelsburg. Ein Heimatbuch, Stettin 1938, s. 449, 473; E. Gohrbandt, Ortsgeschichte, w: Der Kreis Rummelsburg..., s. 183-184; E. v. Puttkamer, Geschichte des Gesellechts v. Puttkamer, 2. Aufl., Neustadt a.d. Aisch 1984, s. 105, 109, 359-360.

${ }^{53}$ AP Szczecin, Konsystorz, 446, f. 207 i n.; 547, f. 82 i n.; 450, s. 27-33; 460, f. 113 i n.; 462, f. $9,57-58 ; 463$, f. 3 i n. 
Z powyższego widać, że żadna ze szkół szlacheckich synodu słupskiego nie spełniała warunków uzyskania środków z funduszu szkolnego, a mimo tego je otrzymały. Największy na to wpływ miał tajny radca von Brenckenhoff, pozostający ze wszystkimi patronami szkół w bliskich stosunkach, o czym doskonale wiedzieli prepozyt Haken, poszczególni pastorzy jako lokalni inspektorzy szkolni oraz władze w Szczecinie. Ich opinie były dlatego zgodne z życzeniem szlacheckich właścicieli wsi.

Pierwsze lata systemu szkół łaski na Pomorzu były pasmem niepowodzeń, a jedną z przyczyn był brak budynków szkolnych/izb lekcyjnych na całym Pomorzu i we wszystkich typach własności. Latem 1777 roku Konsystorz uznał za bardzo pilną budowę 35 budynków dla szkół łaski. Generalne Dyrektorium szacowało koszty budowy szkoły na 15 talarów, zaś pomorski mistrz budowlany wskazywał 182 talary. Berlin takiego kosztorysu nie zaakceptował i w praktyce do końca 1779 roku nic lub prawie nic w zakresie budownictwa nowych szkół nie zrobiono. Dopiero rozkaz Fryderyka II z 4 marca 1780 roku stanowił pewną cezurę, gdyż król zatwierdził kwotę 7350 talarów na budowę 31 nowych szkół i remont 12 (przy czym koszty wzniesienia nowej szkoły nie mogły przewyższać 150 talarów). Jeszcze tego roku Konsystorz liczbę brakujących szkół zwiększył do 49. Największe braki występowały w domenach Drahim, Kołbacz, Podlesie i Marianowo. Kiedy i ile $\mathrm{z}$ nich wzniesiono lub wyremontowano nie udało się ustalić. Pewne jest, że problem budynków szkolnych w latach osiemdziesiątych XVIII wieku udało się - bynajmniej w domenach zachodniej części Pomorza Tylnego - jeśli nie rozwiązać, to w każdym razie złagodzićs ${ }^{4}$. Dopiero wówczas liczba szkół łaski rzeczywiście funkcjonujących stawała się coraz bardziej stabilna. Do tego czasu była ona mobilna i niepodobna określić liczby szkół rzeczywiście działających. Tezy te bardzo dobrze potwierdzają statystyki szkół łaski z 1780 i 1782 roku. W 1780 roku 4626 talarów funduszu szkolnego formalnie było rozdysponowanych między 76 nauczycieli/szkół, z czego 52 (68,5\%) znajdowało się pod patronatem królewskim, 19 (25\%) - szlacheckim i 5 (6,5\%) - miejskim. Jeszcze korzystniej dla domen przedstawiał się kwotowy podział funduszu, bo szkoły we wsiach państwowych uzyskały aż 74,3\% jego całości, szlacheckich - 21\%, zaś miejskich $4,7 \%$. Pensje w domenach były więc najwyższe i średnio kształtowały się w granicach 66 talarów, szlacheckich - 51, zaś miejskich 44 talary. Najbardziej

${ }^{54}$ AP Szczecin Konsystorz, 440, f. 114; 441, f. 111 i n.; 442, f. 185 i n.; 547, f. 189-191, 204-205; 463, f. 203 i n.; F. Koch, Fürst und die Schule..., s. 49; F. Vollmer, Die preußische Volksschulpolitik..., s. 171-173. 
uprzywilejowane były domeny kołbacka i drahimska. Ogólnie - nadodrzańskie domeny, przez które prowadziły trakty komunikacyjne z Berlina i Kostrzyna do Stargardu i Szczecina, którymi Fryderyk II przyjeżdżał na coroczne manewry wojskowe w okolicy Stargardu, skąd niekiedy udawał się również przez Szczecinek - Chojnice do Kwidzyna. Z siecią dróg łączy się też dosyć duża liczba szkół łaski we wsiach szlacheckich synodu Żalecino ${ }^{55}$.

Widać, że niezmiennie od 1776/1777 roku priorytet w rozdziale funduszu szkolnego miały dobra państwowe, a w ich ramach osady założone w czasie kolonizacji fryderycjańskiej, zwłaszcza domeny Podlesie, Kołbacz i Pyrzyce. Często bywało, że w koloniach nie było budynków szkolnych i nauczycieli, a przyznane im były pensje, z reguły najwyższe (80 talarów), po to, aby jak najszybciej doszło do uruchomienia placówek. Gdy chodzi o szkoły w dobrach szlacheckich, to wykaz z 1780 roku w całości potwierdza zgłoszoną już tezę, że uprzywilejowane było bogate i średnie junkierstwo związane z pruskim korpusem oficerskim i aparatem biurokratycznym, które w największym stopniu korzystało z funduszy melioracyjnych.

Raz jeszcze pragniemy podkreślić, że chociaż w 1780 roku formalnie przyznano pensje 76 nauczycielom/szkołom, to nie oznacza, że tyle szkół rzeczywiście działało. W świetle wykazu - najpewniej z 1782 roku - rzeczywiście działały 44 szkoły łaski, w tym 3 reformowane, natomiast nie wypłacono dotąd żadnych środków finansowych nauczycielom/szkołom w 34 miejscowościach, bo „albo brakowało budynków szkolnych, albo zapotrzebowanie na nauczyciela nie zostało zaspokojone" \$6 . Najwięcej budynków szkolnych, bo aż 8, brakowało w domenie drahimskiej i szadzkiej (3). Trzeba dodać, że wśród 44 nauczycieli otrzymujących pensje z państwowego funduszu szkolnego byli tacy, którzy nie wywiązywali się z obowiązków. W czasie wizytacji słupskiego prepozyta Hakena, przeprowadzonych wiosną-latem 1782 roku, nie zgłoszono większych zastrzeżeń do nauczycieli z Machowinka i Świecichowa, chociaż nie byli oni nauczycielami kwalifikowanymi ${ }^{57}$. Diametralnie inna była sytuacja szkoły w Wierszynie. W czasie wizytacji kościoła w Kołczygłowach do egzaminu przedkonfirmacyjnego przystąpiło tylko 10 dzieci z Wierszyna, z których troje wykazało się zadowalającą znajomością chrześcijaństwa. Prepozyt dlatego uznał za rzecz pilną przeprowadzenie

${ }^{55}$ AP Szczecin, Konsystorz, 547, b.f.; L.W. Brüggemann, Ausführliche Beschreibung..., T. I, s. CCLXIII, CCLXXXV; tenże, Beiträge (1806)..., s. 350.

${ }^{56}$ AP Szczecin, Konsystorz, 446, f. 199-201.

${ }^{57}$ AP Szczecin, Konsystorz, 453, f. 50; 547, f. 75-78, 81; 548, f. 90a-92a; 453, f. 50. 
wizytacji w wierszyńskiej szkole łaski, do czego nie chciał dopuścić jej patron von Puttkamer. Kiedy po długich przetargach doszła ona do skutku, prepozyt w jej trakcie został „źle i nieprzyzwoicie” potraktowany przez v. Puttkamera. Haken stwierdził, że absencja niektórych dzieci sięga 60 dni i szkoła realizuje zadania najwyżej w połowie. W końcu stwierdził krótko: „Szkołą łaski w Wierszynie nie będę się dalej martwił" i dał Konsystorzowi wyraźnie do zrozumienia, że nauczyciel/szkoła nie zasługuje na pensję z państwowego funduszu szkolne$\mathrm{go}^{58}$. Nie ulega więc wątpliwości, że środki z funduszu szkolnego nie zawsze były racjonalnie i efektywnie wykorzystane, o czym wiedział Konsystorz, ale, wobec mających silną pozycję polityczną generalnych zarządców domen i junkrów, był bezradny.

Ważnym wydarzeniem w rozwoju szkolnictwa na Pomorzu pruskim było objęcie w kwietniu 1783 roku funkcji dyrektora Konsystorza, zaś rok później prezydenta Zarządu Pomorza przez Juliusa E.W.E. von Massowa (1750-1816), od 1798 roku ministra sprawiedliwości, właściwego również dla spraw kościelnych i szkolnych Prus, który był światłym i pracowitym urzędnikiem, przywiązującym do spraw szkolnictwa elementarnego dużą wagę ¿ $^{59}$ W 1797 roku opublikował utrzymane w duchu Oświecenia Ideen zur Vorbesserung des öffentlichen Schulund Erziehungswesens, mit besonderer Rücksicht auf die Provinz Pommern ${ }^{60}$.

Dyrektor v. Massow 23 października 1783 roku, czyli po pół roku urzędowania, przedstawił ministrowi von Zedlitzowi niektóre problemy (dotyczące budynków szkolnych, szkół zimowych i letnich, nauczycieli, stosunku ludności wsi do szkół) niekorzystnie rzutujące na pomorskie szkolnictwo wiejskie oraz bezowocność dotychczasowych działań, czego dowodzą katalogi szkolne. Poprawę istniejącej sytuacji przynieść miały dalsze normatywy dyscyplinujące kler i patronów. Problem szkół łaski w swym wystąpieniu pominął. Czego jak czego, ale rozkazów, zarządzeń i instrukcji w sprawie szkolnictwa w państwie pruskim nie brakowało; problem był z ich realizacją. Minister zażądał dlatego pogłębionej analizy przedstawionych kwestii i nadesłania - do aprobaty - propozycji działań

58 Tamże, 453, f. 48 n., 86 n.

${ }^{59}$ E. Friedaender, Massow Julius Eberhardt von, „Allgemeine Deutsche Biographie” 1876, t. 20, s. 573; W. Massow, Die Massows. Gesichte einer pommerscher Adelsfamilie, Halle 1931, s. 216-220; Z. Szultka, Stosunek prezydenta Zarzadu Pomorza i pruskiego ministra sprawiedliwości Juliusa Eberhardta W.E. v. Massowa wobec języka kaszubskiego, „Acta Cassubiana” 2012, nr 14, s. 125-126.

60 „Annalen des Preußischen Schul- und Kirchenwesens” 1800, nr 1, s. 76-143; nr 2, s. 181-280; nr 3, s. 361-395. 
mających poprawić sytuację pomorskiego szkolnictwa. Dał wyraźnie do zrozumienia, że poprawa szkolnictwa jest sprawą Pomorzan ${ }^{61}$.

Prezydent von Massow 24 stycznia 1784 roku odpowiedział, że stan szkolnictwa jest skutkiem nieprzestrzegania edyktów szkolnych z 1735 i 1763 roku, to zaś wynika z nieznajomości i nieposzanowania przez społeczeństwo zasad chrześcijaństwa, czego nauczyciele nie są w stanie dokonać bez ściślejszego nadzoru kleru. Jedynie tą drogą można pogłębić znajomość zasad chrześcijaństwa wśród dzieci, których należy uczyć również „innej powszechnie użytecznej wiedzy dla oświecenia rozumu i poprawy serca". Konieczne jest dlatego zaprowadzenie szkół letnich i ożywienie budownictwa szkolnego ${ }^{62}$. Tego samego dnia v. Massow skierował do patronów kościołów na Pomorzu cyrkularz, w którym zwracał uwagę, że bez ich poparcia ożywienie szkolnictwa, głównie na wsi, nie będzie możliwe. Domagał się od nich większego zaangażowania i ofiarności na rzecz szkół. Widać, że prezydent rozumiał problemy pomorskiego szkolnictwa wiejskiego.

29 stycznia 1787 roku von Massow zażądał od superintendentów wypełnienia cyrkularza, będącego formą rozbudowanego katalogu. Jego prawidłowe wypełnienie (w ciągu 6 tygodni) mogło dostarczyć szczegółowych informacji o każdej szkole, w tym również o szkołach łaski, które miały być zwizy towane przez prepozytów.

Odpowiedzi superintendentów napływały nieterminowo, niektóre po trzech latach. Tylko nieliczne mogły zadowolić, bo większość była lakoniczna i niepełna. Konsystorz był bezsilny, groźby kar pieniężnych nie skutkowały. Wykazały, że szkolnictwo wiejskie na Pomorzu pruskim było ogromnie zróżnicowane, najlepiej rozwinięte w synodzie gryfińskim, najsłabiej zaś w pasie nadmorskim ${ }^{63}$.

Po terminie, bo 27 maja 1784 roku prepozyt słupski Haken prosił Konsystorza, aby w jego imieniu wizytacje szkół łaski w Wierszynie i Wiatrołomie przeprowadził pastor wałdowski, zaś w Świecichowie - gardneński. Konsystorz przychylił się do prośby chorego Hakena i o swej decyzji powiadomił patronów wymienionych szkół. Właściciel Wierszyna i Wiatrołomu 4 sierpnia poinformował Konsystorz i wałdowskiego pastora, że do wizytacji może dojść dopiero po jesiennych zasiewach. Konsystorz tego terminu nie zaakceptował, więc von Puttkamer odpowiedział, że nie dostarczy wałdowskiemu proboszczowi powozu

${ }^{61}$ AP Szczecin, Konsystorz, 455, f. 23 i n.; F. Vollmer, Die preußische Volkschulpolitik..., s. $257-258$.

${ }^{62}$ AP Szczecin, Konsystorz, 455, f. 31-32.

${ }^{63}$ AP Szczecin, Konsystorz, 445, f. 4 i n., F. Vollmer, Die preußische Volksschulpolitik..., s. $259-261$. 
i nie wypłaci 1 talara diety wizytacyjnej. 14 listopada 1784 roku proboszcz zrezygnował z dalszych prób przeprowadzenia wizytacji omawianych szkół, zaś prepozyt Haken prosił Konsystorz o przedłużenie terminu ich wizytacji do lata następnego roku. 26 września 1785 roku prosił o prolongatę terminu wizytacji do lata 1786 roku, zaś 6 lipca tego roku poinformował Konsystorz, że nie będzie w stanie przeprowadzić wizytacji tych szkół łaski ${ }^{64}$. Sprawozdanie, które miało być sporządzone w ciągu 6 tygodni, nie zostało wykonane przez 4 lata.

Sprawie tej poświęcono tak wiele miejsca, aby zwrócić uwagę na wielkie trudności towarzyszące badaniom nad szkołami łaski, dodając, że przypadek prepozyta Hakena nie był odosobniony. Do końca 1785 roku Konsystorz nie dostał kilku sprawozdań od superintendentów, mimo że groził im karami finansowymi, w tym np. od kołbackiego, na obszarze którego znajdowało się ponad 20 szkół łaski $^{65}$. To zrozumiałe, że materiały dotyczące zwykłych - patronackich elementarnych szkół wiejskich są jeszcze skromniejsze i bardziej niekompletne, gdyż kościelne władze oświatowe były bezsilne wobec dzierżawców domen i szlachty. Ponadto dla większości pomorskiego kleru sprawy szkolne były bardzo poważnym obciążeniem, od którego nie były w stanie się uwolnić.

Powołane w 1787 roku Naczelne Kolegium Szkolne (Oberschulkollegium), pierwszy w państwie pruskim świecki organ władzy państwowej do spraw szkolnictwa, zażądało od konsystorzy informacji o stanie szkolnictwa w poszczególnych częściach kraju. Prezydent v. Massow w imieniu zarządu Pomorza i Konsystorza w Szczecinie we wrześniu 1788 roku opracował obszerny memoriał o ustroju i stanie całego szkolnictwa pomorskiego oraz możliwościach przełamania jego stagnacji i kryzysu. Niestety w dokumencie tym, utrzymanym w duchu idei Oświecenia, systemowi szkół łaski poświęcono niewiele miejsca. Było ich 86, w tym trzy reformowane. 81 położonych było na Pomorzu Tylnym, zaś pięć na Przednim ${ }^{66}$. W porównaniu z kwietniem 1784 roku ich liczba wzrosła o pięćc ${ }^{67}$. Wydaje się, że przemilczenie szkół łaski w memoriale nie było przypadkowe. Do tego czasu von Massow i Konsystorz nie mogli się nimi chwalić.

\footnotetext{
${ }^{64}$ AP Szczecin, Konsystorz, 455, f. 16-17, 49, 52-55, 61, 114-115 i n; E. Vollmer, Die preußische Volksschulpolitik..., s. 167-168.

${ }^{65}$ AP Szczecin, Konsystorz, 455, f. 100 i n.

${ }^{66}$ Auszug aus einem Bericht der Pommerschen Regierung und des Pommerschen Konsistorium zu Stettin über die Verfasserung der Schulanstalten in dem Herzogtum Pommern, „Pommersch Blätter für die Schule und ihre Freunde" 1904, t. 28 (6), s. 44.
}

${ }^{67}$ AP Szczecin, Konsystorz, 455, f. 1-3. 
Jedną z ważnych przyczyn wielkiego zróżnicowania sieci i organizacji szkół wiejskich, zarówno finansowanych z funduszu szkolnego, jak i pozostających poza tym systemem, był stosunek i zaangażowanie superintendentów synodów w sprawy szkolnictwa. Prezydent v. Massow nie raz podnosił, że ożywienie szkolnictwa w dużym stopniu zależy od postawy superintendentów. Z całą pewnością wyróżniającą wśród nich postacią był superintendent Wierzbna w latach 1775-1797, wcześniej archidiakon Kościoła Mariackiego i profesor gimnazjum w Szczecinie Otto F.G. Vogel (1736-1797), który miał dobre przygotowanie pedagogiczne. Był człowiekiem pracowitym, ofiarnym i oddanym sprawom szkolnictwa, dlatego był wysoko oceniany nie tylko przez władze pomorskie, ale również przez Naczelne Kolegium Szkolne i ministra Johanna Ch. Wöllnera (1732-1800) ${ }^{68}$. Pastor Vogel w 1790 roku został powołany przez Naczelne Kolegium Szkolne na radcę szkolnego i inspektora szkół wiejskich synodów Banie, Gryfino, Kołbacz, Pyrzyce i Wierzbno, w związku z czym nadzorował ponad połowę szkół łaski ${ }^{69}$.

Inspektor corocznie wizytował szkoły wymienionych synodów, niektóre dwukrotnie w ciągu roku, sporządzając obszerne i krytyczne protokoły, przekazywane i analizowane w Szczecinie przez Konsystorz i von Massowa jako prezydenta Zarządu Pomorza, sprawującego zwierzchnią władzę nad Konsystorzem, a następnie w Berlinie, gdzie wielokrotnie je analizowano i oceniano, często wydając polecenia Konsystorzowi. Vogel charakteryzował wszystkie szkoły, ale zawsze najbardziej interesowały go szkoły łaski. Najczęściej wizytował domenę Kołbacz, bo w niej było ich najwięcej (nauczycieli otrzymujących pensję 80 talarów). Uważał, że „koloniści nie doceniają i nie wykorzystują dobrodziejstw” tych szkół. Z drugiej strony piętnował zaprowadzenie przez władze tej domeny opłaty szkolnej, która spowodowała ,że wiele szkół tego roku (1791) było mniej nawiedzanych” przez dzieci. Piętnował niezgodne z założeniami wykorzystywanie środków z funduszu szkolnego (pomijanie premiowania dzieci). Wielokrotnie wnioskował o podjęcie przez justycjariuszy kroków karnych w stosunku do rodziców nieposyłających dzieci do szkół, zwłaszcza w okresie letnim. Przywiązywał wielką wagę do stosunku prepozytów i pastorów do szkolnictwa. Nieraz z nazwiska wymienił pastora, którego uznał winnym nieprawidłowego funkcjonowania szkoły lub braku nauczyciela, z drugiej

${ }^{68}$ H. Moderow, Die evangelischen Geistlichen Pommerns..., s. 53, 461, 622.

${ }^{69}$ AP Szczecin, Konsystorz, 486, f. 53-54; 488, f. 51. 
strony chwalił zaangażowanych. Miał bardzo krytyczny stosunek do nauczycieli szkół łaski, których był postrachem, wielu z nich obniżył pensje ${ }^{70}$.

Efekty działalności Vogla były widoczne już po 3-4 latach. Tak oceniały jego pracę władze w Szczecinie i Berlinie. Minister Johann Ch. Wöllner 17 grudnia 1793 roku pisał: „Z wielką radością przyjęliśmy, że 92 szkoły są w dobrym stanie organizacyjnym i w licznych innych, od ostatnich wizytacji, zaszły celowe poprawy w zakresie spraw zewnętrznych i wewnętrznych", chociaż jeszcze w 21 szkołach występowały niedostatki. Miesiąc później Wöllner prosił Vogla o przedłużenie propozycji zmian w zakresie wysokości pensji nauczycieli ${ }^{71}$, które z pewnością otrzymał. Od 1793 roku krytycznych uwag o stanie szkół i ich nauczycielach było coraz mniej. Można bez przesady stwierdzić, że od połowy lat dziewięćdziesiątych XVIII wieku szkoły łaski w pięciu nadodrzańskich synodach były faktycznie szkołami, korzystnie oddziałującymi na placówki patronackie, pod adresem których krytycznych uwag inspektor Vogel miał również coraz mniej. Odnosi się to do szkół we wszystkich typach własności ziemskiej. W ostatnich latach XVIII wieku szkoły patronackie w wymienionych pięciu synodach ustępowały szkołom łaski przede wszystkim warunkami nauczania i kwalifikacjami nauczycieli.

Jaskrawym zaprzeczeniem stanu szkolnictwa, w tym szkół łaski, w synodach nadodrzańskiej części Pomorza było szkolnictwo wiejskie synodu szczecineckiego, w którym w 1794 roku znajdowało się osiem szkół łaski (6 w domenie Szczecinek, 2 we wsiach szlacheckich - Juchowo, Lotyń). Szczecinecki prepozyt i inspektor szkolny miejscowego gimnazjum Johann D. Drews (1786-1815), wcześniej rektor w Pełczycach i kapelan regimentowy, 21 marca 1794 roku przesłał Konsystorzowi w Szczecinie informację o stanie szkolnictwa wiejskiego w synodzie, w której uwzględniono też szkoły łaski ${ }^{72}$. Stwierdził, że w synodzie „,właściwie nie można było” zaprowadzić szkół letnich, bo „karami niczego tu nie osiągnięto”, a napomnienia rodziców są całkowicie bezowocne, gdyż chłopi brakującą służbę zastępują swymi dziećmi, które wykorzystywane są do najróżniejszych prac polowych i domowych. Szkoły letnie są dlatego bardzo nieliczne i chodzą do nich tylko najmniejsze dzieci. $Z$ tego powodu przed paru laty Drews zastąpił je ,popołudniowymi szkołami niedzielnymi”, prowadzonymi przez zakrystianów w kościołach lub przez nauczycieli w szkołach, gdzie

${ }^{70}$ Tamże, f. 62 i n.; 488, f. 2 i n.

${ }^{71}$ AP Szczecin, Konsystorz, 488, f. 50-53.

${ }^{72}$ AP Szczecin, Konsystorz, 488, f. 55; E. Müller, Die evangelischen Geistlichen Pommerns von der Reformation bis zum Gegenwart. T. II: Der Regierungsbezirk Köslin, Stettin 1912, s. 267. 
większe dzieci uczy się zasad chrześcijaństwa i czytania. Nauczyciele szkół łaski prowadzą je bezpłatnie, zaś pozostali są wynagradzani z kasy kościelnej. Szkół tych nie udało się do 1794 roku zorganizować we wszystkich parafiach synodu ${ }^{73}$.

Widać, że podstawą ustroju szkolnictwa wiejskiego synodu szczecineckiego w 1794 roku był edykt z 1735 roku. Dla jego superintendenta regulamin z 1763 roku oraz instrukcja określająca system szkół łaski nie miały większego znaczenia, w każdym razie nie czuł się zobowiązany ich przestrzegać. Szkoły łaski traktował jak zwykłe szkoły patronackie, chociaż różniły się sposobem finansowania $\mathrm{i}-\mathrm{z}$ dalszego wywodu wynika - poziomem nauczania. W synodzie miały obowiązywać te same podręczniki wprowadzone „królewskim rozkazem”, których bliżej nie określono, ale dzieci szkół patronackich - w przeciwieństwie do szkół łaski - ich nie rozumiały, mimo że prepozyt zobowiązał pastorów, aby pouczyli nauczycieli o metodach korzystania z nich ${ }^{74}$. Widać, że w szkołach łaski uczyli lepiej wykwalifikowani nauczyciele. Różnic między ostatnimi a patronackimi szkołami łaski było zapewne więcej, co nie zmienia faktu, że szkoły łaski w synodzie szczecineckim oraz słupskim i pięciu wyżej omawianych - dzieliła przepaść. Jedną z bardzo ważnych tego stanu przyczyn było ograniczenie nadzoru nad szkołami łaski przez Konsystorza do synodów najbliżej położonych Szczecina, w których prowadzono intensywną kolonizację.

Generalny superintendent Pomorza pruskiego i Konsystorz nie mogli zignorować informacji prepozyta Drewsa i zobowiązali go oraz domenialnego justycjariusza do podjęcia działań w celu pełnej realizacji zobowiązań ciążących na nauczycielach opłacanych z funduszu szkolnego. Efektów tych działań nie znamy $^{75}$, ale należy podkreślić polecenie zaangażowania w rozwój szkolnictwa urzędu justycjariusza ${ }^{76}$, z którym tak skutecznie współpracował inspektor Vogel.

Wydaje się, że podniesione zróżnicowanie szkół łaski było charakterystyczne dla całego Pomorza pruskiego i w początkach XIX wieku miało ostrzejszy niż wcześniej wymiar, co zaprezentowano w tabeli 1.

\footnotetext{
${ }^{73}$ AP Szczecin, Konsystorz, 488, f. 55.

${ }^{74}$ Tamże, f. 55 i n.

75 Tamże, f. 57 i n.

${ }^{76} \mathrm{P}$. Gut, Powstanie królewskiego sądownictwa w pruskich domenach $w$ XVIII wieku na przykładzie prowincji pomorskiej, w: Studia archiwalne - historyczne - politologiczne, red. A. Czubiński, J. Macholak, Szczecin 2003, s. 16-17, 20-21.
} 
Tabela 1. Podział pomorskiego funduszu szkolnego pomiędzy nauczycieli/szkoły w 1804 roku

\begin{tabular}{|c|c|c|c|}
\hline Wyszczególnienie & Liczba nauczycieli & $\begin{array}{l}\text { Wysokość funduszu } \\
\text { (w talarach) }\end{array}$ & Średnia pensja \\
\hline 1 & 2 & 3 & 4 \\
\hline \multicolumn{4}{|c|}{ Wsie państwowe } \\
\hline Domena Bobolice & 1 & 40 & \\
\hline Domena Drahim & 6 & 320 & \\
\hline Domena Kołbacz & 27 & 1288 & \\
\hline Domena Marianowo & 6 & 427 & \\
\hline Domena Podlesie & 6 & 232 & \\
\hline Domena Pyrzyce & 4 & 184 & \\
\hline Domena Szadzko & 5 & 348 & \\
\hline Domena Szczecinek & 7 & 356 & \\
\hline Domena Königsholland & 2 & 120 & \\
\hline Domena Pudagla & 1 & 29 & \\
\hline Domena Ückermünde & 2 & 52 & \\
\hline Razem & 67 & 3396 & 50,7 \\
\hline \multicolumn{4}{|c|}{ Wsie szlacheckie } \\
\hline Synod Białogard & 1 & 40 & \\
\hline Synod Bobolice & 1 & 40 & \\
\hline Synod Dobra & 1 & 29 & \\
\hline Synod Gryfino & 1 & 80 & \\
\hline Synod Karlino & 1 & 40 & \\
\hline Synod Kołobrzeg & 1 & 40 & \\
\hline Synod Pyrzyce & 1 & 75 & \\
\hline Synod Sławno & 1 & 40 & \\
\hline Synod Słupsk & 4 & 200 & \\
\hline Synod Szczecinek & 2 & 149 & \\
\hline Synod Wierzbno & 5 & 238 & \\
\hline Razem & 19 & 944 & 49,7 \\
\hline \multicolumn{4}{|c|}{ Wsie miejskie } \\
\hline Gryfina & 1 & 26 & \\
\hline Pyrzyc & 1 & 43 & \\
\hline Stargardu & 1 & 40 & \\
\hline Szczecina & 3 & 174 & \\
\hline Razem & 6 & 283 & 47,2 \\
\hline Razem & 92 & 4623 & 50,25 \\
\hline
\end{tabular}

Źródło: L.W. Brüggemann, Beiträge (1806)..., s. 350. 
W rozdziale środków z funduszu szkolnego od początku lat osiemdziesiątych XVIII wieku do pierwszych lat następnego stulecia nie zaszły poważniejsze zmiany - najważniejszą było wyrównanie pensji nauczycieli. Średnie wynagrodzenie nauczycieli w szkołach we wszystkich trzech typach własności wynosiło około 50 talarów. 17 nauczycieli otrzymywało po 80 talarów, 33 - po 40, najmniej nauczyciel z Wirowa koło Gryfina - tylko 6 talarów. W dalszym ciągu wzrastała liczba nauczycieli/szkół korzystających ze środków państwowych (z 86 w 1788 r. do 92 w 1804 r.), niezmiennie priorytet w zakresie liczby szkół i wielkości środków zachowywały szkoły w dobrach państwowych (odpowiednio 73\% i $73,5 \%$ ). Na szkoły w dobrach szlacheckich przypadało nieco ponad $20 \%$ środków (i nauczycieli), zaś we wsiach miejskich było ich około 7\%. Uprzywilejowane pozostawały osady kolonizacyjne. Prawie 90\% szkół łaski położonych było w pasie nadodrzańskim i przytłaczająca ich większość podlegała Konsystorzowi w Szczecinie i nadzorowi inspektora Vogela. Na nich koncentrowała się uwaga i działalność reformatorska pomorskich i centralnych władz oświatowych.

W przeciwieństwie do skoncentrowanej sieci szkolnej w domenach i wsiach miejskich szkoły łaski w dobrach szlacheckich były bardzo rozproszone. Jedynie w synodzie Wierzbno (Żalęcino), przez który biegły trakty komunikacyjne łączące Szczecin i Stargard z Berlinem i Kostrzynem, było ich pięć. Patronami większości szkół we wsiach szlacheckich pozostawali wysocy oficerowie i urzędnicy pruskiego aparatu biurokratycznego.

Widać, że system szkół łaski na Pomorzu w latach 1777-1804 uległ głębokiej ewolucji. Liczba planowanych w 1773 roku 40 szkół z pensją 80 talarów w 1777 roku wzrosła do 76 z pensją 60 talarów, by w 1804 roku zwiększyć się do 92, z wynagrodzeniem 50 talarów. Konsekwencją wzrastającej liczby szkół łaski był równoczesny spadek pensji, która mimo tego była średnio co najmniej dwukrotnie wyższa niż w zwykłych szkołach patronackich. Ten kierunek przemian szkół łaski uznajemy za prawidłowy i trafny, bo szkoły łaski - jak zobaczymy - były lepiej zorganizowane i reprezentowały wyższy poziom nauczania niż elementarne szkoły patronackie. Największym ich atutem była relatywnie wysoka pensja kwalifikowanego nauczyciela, dlatego rodzice byli zwolnieni nie tylko z opłaty szkolnej, ale również z kupowania podręczników i innych pomocy szkolnych. Jak wielkie były różnice $\mathrm{w}$ zakresie metod i treści nauczania, a przede wszystkim skali obowiązku szkolnego dzieci, między szkołami łaski a zwykłymi placówkami patronackimi można przedstawić na przykładzie synodu dobrzańskiego w 1806 roku, w którym znajdowało się 36 szkół, ale analizą objęto tylko 34 z nich. 
Tabela 2. Szkolnictwo w synodzie dobrzańskim w 1806 roku

\begin{tabular}{|c|c|c|c|c|}
\hline \multicolumn{5}{|c|}{ I. Szkoły pod patronatem królewskim } \\
\hline \multirow{2}{*}{1.} & \multirow{2}{*}{ Nauczyciele finansowani z funduszu szkolnego } & \multirow{2}{*}{ Liczba wsi } & \multicolumn{2}{|c|}{ Liczba szkół } \\
\hline & & & zimowe & letnie \\
\hline & 1. Domena Marianowo & 5 & 5 & 5 \\
\hline & 2. Domena Szadzko & 4 & 4 & 4 \\
\hline & Razem & 9 & 9 & 9 \\
\hline 2. & Nauczyciele finansowani z opłat szkolnych & & & \\
\hline & 1. Domena Dolice & 6 & 6 & 6 \\
\hline & 2. Domena Marianowo & 2 & 2 & 2 \\
\hline & 3. Domena Szadzko & 10 & 10 & 10 \\
\hline & Razem & 18 & 18 & 18 \\
\hline & & 27 & 27 & 27 \\
\hline & $\begin{array}{l}\text { zkoły pod patronatem szlacheckim finansowane } \\
\text { łat szkolnych }\end{array}$ & $7^{*}$ & 7 & 3 \\
\hline & & 34 & 34 & 30 \\
\hline
\end{tabular}

* Informacje dotyczące szkół w Dobropolu Gryfińskim (Doberphul) i Ziemomyśle (Schönwerder) pochodzą z katalogu szkolnego z 1788 r. Szkoła w Golinie była wspólna dla dzieci z tej wsi i Barzkowic.

Źródło: AP Szczecin, RS., 1594, b.f.

W 1806 roku średnia pensja łaski dziewięciu nauczycieli domen Marianowo i Szadzko wynosiła 70 talarów ${ }^{77}$. Chociaż byli oni zobowiązani - jak zobaczymy - do określonych świadczeń na rzecz szkoły i uczniów właśnie z tytułu otrzymywania pensji łaski, mimo tego zaliczani być mogą do wiejskiej elity nauczycielskiej, bo dochody z drugiego wykonywanego zawodu - rzemiosła, w przytłaczającej większości krawiectwa - były zacznie niższe. Niektórzy z nich deklarowali, że zrezygnowali z rzemiosła jako dodatkowego zajęcia i źródła dochodów.

Nauczyciele szkół łaski synodu dobrzańskiego korzystali też z innych stałych i niestałych dochodów. Większość dysponowała chatami, gdzie mieszkali, szkołami i warsztatami pracy, przydomowymi działkami i ogrodami, jakimiś łąkami, niektórzy mieli prawo wypasu 1-2 krów na rozłogach gminnych i otrzymywali bezpłatny opał od patrona lub gminy (rodziców uczonych dzieci) w formie opłaty szkolnej.

Drugim źródłem opłacania nauczycieli wiejskich w synodzie dobrzańskim, we wsiach domenialnych i szlacheckich, były opłaty szkolne, formalnie od 1763 roku jednolite w skali kraju, w praktyce zaś różniące się nie tylko w każdej domenie, ale też wsi. $Z$ reguły inna była opłata za naukę dziecka w szkole zimowej

${ }^{77}$ AP Szczecin, Rękopisy i Spuścizny (dalej RS.), 1594, f. 55 i n. 
- najczęściej wyższa, niższa zaś w szkole letniej. Często za naukę w okresie letnim dzieci nie płaciły. Wysokość opłaty szkolnej zależała również od umiejętności dzieci nabytych w szkole, na przykład - w domenie Dolice w Suchanówku opłata zimowa wynosiła 5 groszy 4 szelągi, w Sadłowie natomiast rodzice dziecka umiejącego czytać płacili 9 groszy, zaś tylko sylabizującego - 6 groszy, natomiast w Suchaniu dziecko czytające, piszące i rachujące płaciło kwartalnie 6 groszy, czytające -4 , znające litery i sylabizujące -2 grosze $^{78}$. Z reguły w każdej szkole rodzice najbiedniejszych dzieci (od jednego do trójki) byli zwolnieni z opłaty szkolnej. Widać, że wysokość opłaty szkolnej poważnie wpływała na dochody nauczyciela; jeszcze większa zależność dotyczyła liczby uczniów - o czym więcej niżej. Za reprezentatywne uznajemy pensje/dochody nauczycieli z opłat szkolnych domeny Marianowo, wynoszące średnio 8 talarów 12 groszy i Szadzko - 10 talarów 14 groszy. Pensja nauczycieli w szkołach pod patronatem szlacheckim wynosiła średnio nieco ponad 13 talarów ${ }^{79}$.

Najważniejszym wyróżnikiem nauczycieli szkół łaski było ich przygotowanie zawodowe. $Z$ wykazu nauczycieli synodu dobrzańskiego z 30 grudnia 1807 roku wynika, że średnia ich wieku wynosiła nieco ponad 50 lat, zaś długość ich pracy jako nauczycieli - 23,5 roku. Najstarszymi nauczycielami byli - 69-letni Dawid Teschendorf uczący od 43 lat w Odargowie oraz 67-letni Friedrich Bugandt, uczący w Marianowie od 39 lat, którzy zdali egzaminy kwalifikacyjne w Szczecinie. Ośmiu pozostałych nauczycieli to absolwenci seminarium nauczycielskiego w Szczecinie, założonego w 1783 roku. Wszyscy nauczyciele funduszu łaski, uczący w szkołach domenialnych synodu dobrzańskiego, byli kwalifikowanymi pedagogami. Wysokość otrzymanej pensji i inne dochody pozwalały im na skoncentrowanie uwagi na szkole i nauczaniu, bo tylko trzech z nich podało, że zajęciem ubocznym jest krawiectwo. Diametralnie niższe były kwalifikacje nauczycieli szkół domenialnych i szlacheckich wynagradzanych z opłat szkolnych. Żaden nie miał przygotowania do zawodu nauczycielskiego. Zakrystian z Pęzina napisał, że na nauczyciela przysposobił go ojciec, zaś z Goliny - „obcy pastor”80.

Nauczyciele szkół domenialnych, wynagradzani z opłat szkolnych mieli taki sam wiek, staż pracy i przygotowanie zawodowe jak nauczyciele szkół we wsiach szlacheckich. Żaden z 18 nauczycieli nie ukończył seminarium nauczycielskiego

\footnotetext{
${ }^{78}$ AP Szczecin, RS., 1594, f. 76, 135, 137.

${ }^{79}$ Tamże, f. 23 n.

${ }^{80}$ AP Szczecin, Konsystorz, 233, b.f.
} 
i nie zdał egzaminu kwalifikacyjnego. Dwóch podało, że przysposobiło się do zawodu w szkole w mieście, jeden w ,,szkole wiejskiej”, innego przygotował ,poprzedni pastor", nauczyciel Jakub Roose, 49-letni krawiec z Czarnkowa napisał, że był „wcześniej wikariuszem”, chociaż uczył już 19 lat ${ }^{81}$.

Z przeprowadzonych rozważań wynika, ze państwowy szkolny fundusz łaski skierowany był przede wszystkim do nauczycieli szkół państwowych/domenialnych. Uposażenie nauczycieli z tego funduszu w synodzie dobrzańskim kształtowało się w granicach 70 talarów rocznie i należało do najwyższych. Było 4-5-krotnie wyższe niż pozostałych nauczycieli, zatrudnianych w szkołach pod patronatem królewskim i szlacheckim. Ich pensje, kształtujące się w granicach 10-15 talarów, uzależnione były od wysokości opłaty szkolnej - bardzo zróżnicowanej w tym zakresie - oraz liczby uczniów. Jeszcze większe były różnice w zakresie umiejętności i kwalifikacji zawodowych. Wszyscy nauczyciele korzystający z funduszu łaski byli kwalifikowanymi pedagogami, tzn. absolwentami seminarium nauczycielskiego lub zdali stosowne państwowe egzaminy kwalifikujące w czasie, kiedy nie kształcono jeszcze nauczycieli w systemie seminaryjnym. Dzięki tym i innym czynnikom (lepsze warunki lokalne szkół łaski) szkoły prowadzone przez nauczycieli łaski z czasem stały się przodującymi, by nie powiedzieć wzorcowymi placówkami wychowawczo-oświatowymi na wsi. Duży na to wpływ wywarła również nieporównanie ściślejsza niż nad pozostałymi szkołami kontrola ze strony Konsystorza, którą w tym miejscu pomijamy.

W tabeli 2 przedstawiono, że między szkołami pod patronatem królewskim i szlacheckim występowały znaczne różnice, co jest lepiej widoczne po analizie katalogu szkolnego, z której jednoznacznie wynika, że najlepiej zorganizowanymi i funkcjonującymi placówkami oświatowymi były szkoły prowadzone przez nauczycieli opłacanych z odsetków funduszu melioracyjnego (tab. 3).

Do szkół (zimowych) tej grupy placówek chodziło 90,5\% dzieci, zaś letnich 68,5\%. Oznacza to, że co dziesiąte dziecko nie chodziło w ogóle do szkoły (zimowej), w ocenie nauczycieli i pastorów głównie z powodu biedy rodziców oraz chorób dzieci, natomiast w okresie letnim co trzeci uczeń nie chodził do szkoły. Jako przyczynę wymieniano najczęściej: bieda rodziców, prace domowe i polowe, wypas bydła, „wynajęcie [dzieci - dop. Z.S.], aby zapracowały na chleb”, przędzenie wełny. Warto zwrócić uwagę, że w domenie Szadzko latem nie uczyło się $19,5 \%$, zaś w domenie Marianowo - 35\%, ale szkoły w tej ostatniej były o ponad

\footnotetext{
81 Tamże.
} 
$40 \%$ liczniejsze. Poziom nauczania w domenie Marianowo był jednak wyższy niż w kluczu szadzkim, chociaż wszystkie zimowe szkoły w obu domenach funkcjonowały zgodnie z regulaminem szkolnym z 1763 roku, tj. nauka odbywała się codziennie w godzinach 8-11 i 13-16. W szkołach domeny Marianowo umiało czytać $76 \%$ uczących się dzieci, pisać - 24,5\%, zaś liczyć - 15\%. Wskaźniki te dla domeny Szadzko wynoszą odpowiednio 74\%, 26,5\% i 12\% (tab. 3).

Tabela 3. Szkolnictwo synodu dobrzańskiego w 1806 roku

\begin{tabular}{|c|c|c|c|c|c|c|c|}
\hline \multirow[b]{3}{*}{ Wyszczególnienie } & \multicolumn{7}{|c|}{ Liczba dzieci } \\
\hline & \multicolumn{5}{|c|}{ szkoła zimowa } & \multicolumn{2}{|c|}{ szkoła letnia } \\
\hline & \begin{tabular}{|} 
objętych \\
obowiąz- \\
kiem \\
szkolnym
\end{tabular} & $\begin{array}{l}\text { uczących } \\
\text { się }\end{array}$ & $\begin{array}{l}\text { czytają- } \\
\text { cych }\end{array}$ & piszących & liczących & $\begin{array}{c}\text { uczących } \\
\text { się }\end{array}$ & $\begin{array}{l}\text { nieuczą- } \\
\text { cych się }\end{array}$ \\
\hline \multicolumn{8}{|c|}{ Szkoły finansowane z funduszu szkolnego } \\
\hline Domena Marianowo & 365 & 318 & 242 & 78 & 48 & 237 & 128 \\
\hline Domena Szadzko & 147 & 146 & 108 & 39 & 18 & 114 & 33 \\
\hline Razem & 512 & 464 & 352 & 117 & 66 & 351 & 161 \\
\hline \multicolumn{8}{|c|}{ Szkoły finansowane z opłat szkolnych } \\
\hline Domena Dolice & \begin{tabular}{l|l}
413 \\
\end{tabular} & 413 & 223 & 78 & 30 & $235^{*}$ & 178 \\
\hline Domena Marianowo & 82 & 82 & 55 & 18 & 4 & 35 & 47 \\
\hline Domena Szadzko & 340 & 340 & 230 & 89 & 28 & 203 & 137 \\
\hline Razem & 835 & 835 & 508 & 185 & 62 & 473 & 362 \\
\hline Wsie szlacheckie ${ }^{* *}$ & 230 & 228 & 152 & 20 & 4 & 80 & 150 \\
\hline RAZEM & 1577 & 1527 & 1012 & 322 & 132 & 904 & 673 \\
\hline
\end{tabular}

* Dla Suchanówka doszacowano 28 dzieci.

*** Dotyczy szkół: Golina-Barzkowice, Pęzino, Radaczewo, Rybaki, Sokoliniec i Ziemomysł (1788). Nie uwzględniono Dobropola Gryfińskiego z uwagi na defekty katalogu tej szkoły.

Źródło: AP Szczecin, RS., 1584, b.f.

$\mathrm{Na}$ pierwszy rzut oka szkoły letnie prezentowały się również korzystniej w domenie Marianowo niż Szadzko, bo działały przez cały tydzień, w Marianowie, Sulinie i Wiechowie od 8 do 11, zaś w największych szkołach - Białej Ińskiej i Lutkowie od 8 do 12. Do szkół nie chodziło jednak aż 35\% dzieci, podczas gdy w domenie Szadzko absencja wynosiła 22,5\%, ale szkoły letnie działały w nich - w uzgodnieniu z rodzicami, jak zapewniali pastorzy - tylko w niektóre dni tygodnia; w Szadzku cztery dni po 3 godziny, w Kępnie i Odargowie po dwa dni przed południem, zaś w Tarnowie również dwa dni, ale przed i po południu po 3 godziny. 
Pastorzy i superintendent byli zadowoleni z takiego stanu szkół prowadzonych przez nauczycieli wynagradzanych z funduszu szkolnego i nie szczędzili pochwał. Z postępów szkolnictwa w domenie Marianowo był zadowolony również minister Johann Ch. Wöllner, czemu dał wyraz 12 czerwca 1792 roku $^{82}$. Pastorzy i superintendenci zapewniali, że ich przekonywania rodziców o korzyściach płynących z nauki ich dzieci spotkały się ze zrozumieniem i nikt złośliwie nie uchylał się od obowiązku szkolnego. Jeśli absencja jest taka, jaka jest, to głównym tego powodem jest ubóstwo rodziców zmuszających dzieci do pracy w obejściu domowym i na polu oraz do wynajmowania dzieci innym osobom, aby zapracowały na chleb. Żaden pastor nie wywiązywał się w pełni z obowiązków nałożonych przez regulamin szkolny i nie uczył tygodniowo cztery godziny w szkole, ale żaden nie uchylał się od obowiązku przeprowadzenia wizytacji szkół w miarę możliwości ${ }^{83}$. Przy sposobności udzielali wskazówek i pouczali nauczycieli, zaś pastor z Lutkowa - jako jedyny zdaje się - prowadził lekcje. Prawie wszyscy pastorzy zwracali uwagę, że nauczanie dzieci, zgodne z ich „zdolnościami” a nie tylko na pamięć, przynosi dobre wyniki.

Wszyscy nauczyciele w szkołach łaski synodu dobrzańskiego zobowiązani byli corocznie przeznaczyć z pensji 16 groszy na „premie”, za które kupowali atrament i materiały piśmienne, ale nie wiadomo czy dla wszystkich, czy też tylko dla najbiedniejszych dzieci ${ }^{84}$. Nie był to najpewniej znaczący ubytek w dochodach nauczycieli, bo nauczyciel z Wiechowa w kwietniu 1806 roku - prócz wspomnianych materiałów do pisania - zakupił ,jako nagrodę za pilność Nowy Testament i stargardzki śpiewnik" (Stargarder Gesangbuch). Trzy egzemplarze tych wydawnictw w tym samym czasie zakupił nauczyciel z Sulina, płacąc 2 talary 18 groszy $^{85}$, a więc więcej niż wynosiła pensja nauczyciela $\mathrm{z}$ domenialnego Ciemnika.

Nauczyciele szkół łaski zaopatrywali swe szkoły w podręczniki szkolne i inne pomoce nauczania. Wiadomo bowiem, że nauczyciele z Białej Ińskiej i Lutkowa wiosną 1806 roku zakupili po 25 egzemplarzy „nowych berlińskich podręczników" (neue Berlinsche Schulbücher) ${ }^{86}$. Prawdopodobnie chodzi o zale-

\footnotetext{
${ }^{82}$ AP Szczecin, Konsystorz, 488, f. 29.

${ }^{83}$ AP Szczecin, RS., 1594, f. 60 i n.

${ }^{84}$ Tamże, f. 60, 66, 85, 99, 108 i n.

${ }^{85}$ Tamże, f. 108, 111.

${ }^{86}$ Tamże, f. 98, 101.
} 
cany w szkołach łaski Catechismus der Sittenlehre für das Landvolk Johanna G. Schlossera oraz słynny podręcznik Friedricha E. Rochowa (1734-1805) Przyjaciel dzieci, który w 1779 roku spotkał się z krytyczną oceną słupskiego superintendenta Christiana W. Hakena. Haken uznał, że nie jest on przydatny zarówno dla nauczycieli, jak i dzieci ${ }^{87}$. Johann D. Blanckenhagen nauczyciel z Białej Ińskiej zakupił ponadto dwie ramy do „małych tablic szkolnych”88. Widać więc, że nauczyciele szkół łaski nie ograniczali się tylko do nauczania dzieci, ale byli rzeczywistymi gospodarzami i kierownikami szkół, zatroskanymi o prawidłowy tok nauczania, szkolne pomoce nauczania, podręczniki szkolne, atrament i papier (zeszyty) dla dzieci. Nauczyciel z Białej Ińskiej uskarżał się na zbyt małą izbę lekcyjną i domagał się jej powiększenia, w czym popierał go pastor z Sulina ${ }^{89}$.

$\mathrm{Na}$ drugim biegunie szkół wiejskich synodu dobrzańskiego znajdowały się placówki pod patronatem szlacheckim. Liczby ich dotyczące, wykazane w tabeli 3 charakteryzują się małą wiarygodnością, są nazbyt optymistyczne. Ogólnie szkoły we wsiach szlacheckich były bardzo zróżnicowane. O ile szkoła zimowa (tylko) w Ziemomyślu nie ustępowała, zaś w Pęzinie była porównywalna z domenialnymi szkołami łaski, o tyle pozostałe szkoły szlacheckie od wymienionych dzieliła przepaść. Wystarczy powiedzieć, że tylko $66,5 \%$ dzieci z tych szkół umiało czytać, niespełna $9 \%$ pisać, zaś $0,2 \%$ liczyć. Szkoły we wsiach szlacheckich ograniczały się więc do nauki katechizmu, podstaw chrześcijaństwa i czytania. Wyjątek stanowiła szkoła w Ziemomyślu, której nauczyciel-zakrystian, krawiec z zawodu, Johann F. Jaenicke swych 70 uczniów podzielił na sześć klas, tworząc dwie klasy sylabizowania, dwie czytania, jedna pisania (kaligraficznego pisania i czytania listów, wypisywania kwitów) i jedną rachowania, w której zwracał uwagę na opanowanie przez uczniów „reguły trzech” (Regeldetri) ${ }^{90}$. Przekonywał, że jemu i pastorowi chodzi o zaszczepienie dzieciom zasad wiary i obyczajności, „ale nie przez proste uczenie się na pamięć, lecz przez praktyczne wskazywanie na zwyczaje i czystość dzieci (...) szczególnie jest im wpajane posłuszeństwo, miłość i podporządkowanie wobec przełożonych i władz" ${ }^{91}$. Dalej pisał, że do szkoły letniej nie chodzi nawet połowa dzieci, bo rodzice wyżej cenią sobie ich pracę niż naukę.

\footnotetext{
${ }^{87}$ AP Szczecin, Konsystorz, 457, f. 73.

${ }^{88}$ AP Szczecin, RS., 1594, f. 101.

${ }^{89}$ Tamże, f. 103.

${ }^{90}$ Regeldetri - reguła trzech działań.

${ }^{91}$ AP Szczecin, RS., 1594, f. 53. Autor pisał 29.01.1798 r.
} 
Postawa rodziców, ściśle łączona z ich biedą, była w opinii pastorów i nauczycieli głównym powodem słabości szkół, zwłaszcza letnich. Rodzice nie byli w stanie płacić za swe dzieci chodzące do szkoły. Z tego powodu w Rybakach 11 uczniów chodziło do szkoły bardzo nieregularnie, zaś 8 nie chodziło w ogóle, bo „oni [rodzice - dop. Z.S.] chcą zaoszczędzić opłatę szkolną”. Aby temu zapobiec, w Sokolińcu i Golini-Barzkowicach za naukę najbiedniejszych dzieci płaciła fundacja ministra hr. v. Blumenthala i marszałka dworu Petera J. v. Forcade. Nawet w Pęzinie, gdzie znajdowała się relatywnie dobra szkoła, część rodziców była całkowicie obojętna wobec nauki swoich dzieci.

Formalnie we wszystkich wsiach szlacheckich szkoły zimowe działały zgodnie z regulaminem szkolnym z 1763 roku, ale w praktyce część dzieci rozpoczynało naukę od św. Michała (29 września), część od św. Marcina (11 listopada), inne od Bożego Narodzenia, a inne jeszcze później - po Nowym Roku. Są powody, aby wątpić w naukę w tych szkołach w godzinach popołudniowych. O podręcznikach czy innych pomocach naukowych nie było mowy, ale zakrystian z Pęzina najpilniejszym uczniom dawał ,papier i pióro”.

Jeszcze gorzej prezentowały się szkoły letnie. Działały one jedynie w trzech (z siedmiu) wsiach szlacheckich, po trzy godziny dwa razy w tygodniu. Uczęszczało do nich zaledwie $35 \%$ dzieci objętych obowiązkiem szkolnym. Nauczyciel z Pęzina pisał, że powodem tak wysokiej absencji było to, że dzieci „muszą paść bydło i orać". Właśnie prace polowe i domowe były głównym zajęciem dzieci latem. Niektórzy pastorzy szkoły letnie próbowali zastąpić niedzielnymi katechezami kościelnymi, prowadzonymi po południu wspólnie z zakrystianami/ nauczycielami. Ogólnie nauczyciele i pastorzy słabość szkół we wsiach szlacheckich próbowali zrzucić na rodziców, chociaż dostrzegali ich nędzę. Żaden nie skierował ani jednego krytycznego zdania pod adresem patronów. Sami też nie czuli się winni. Pastorzy z Pęzina i Rybaków chwalili się, że co tydzień wizytują szkoły, niekiedy kilka razy i przy okazji zwyczajowo prowadzą kilka lekcji ${ }^{92}$.

Szlacheckie szkolnictwo synodu dobrzańskiego pierwszych lat XIX stulecia to typowe szkółki zakrystianów, ukształtowane w okresie rządów Fryderyka Wilhelma I, mocno osadzone w pietyźmie, bojaźni Bożej i posłuszeństwie wobec władzy państwowej i zwierzchności feudalnej. Jedynie w szkole w Ziemomyślu na prądy te nakładały się oświeceniowe tendencje pedagogiczne.

92 Tamże, f. 23 n. 
Podobnie jak w przypadku nauczycieli, szkolnictwo wiejskie w domenach oparte na opłatach szkolnych zajmowało pośrednią pozycję między państwowymi szkołami łaski a szkołami we wsiach szlacheckich. Bliżej było im jednak do szkół łaski niż szkół wsi szlacheckich. Najbardziej wymiernymi czynnikami organizacji i poziomu nauczania w szkołach wiejskich na przełomie XVIII-XIX wieku były liczby dzieci umiejących pisać i czytać w szkołach zimowych, liczba szkół letnich oraz uczących się w nich dzieci. We wsiach szlacheckich były tylko trzy szkoły, do których chodziło niespełna 35\% dzieci objętych obowiązkiem szkolnym, natomiast w 17 wsiach domenialnych funkcjonowało 15 szkół, w których uczyło się 57\% dzieci podlegających obowiązkowi szkolnemu (tab. 3). Szkoły letniej nie było jedynie w Słodkowie, bo - jak pisał pastor - rodzice nie posyłają dzieci latem do szkoły, zaś jego przekonywania nie znajdują posłuchu. „Nic więcej nie mogę zrobić”.

Gdy chodzi o szkoły zimowe w domenach, działające dzięki opłatom szkolnym, to w centrum ich nauczania tradycyjnie pozostawały zasady chrześcijaństwa ujęte w katechizmie oraz nauka czytania, którą opanowało około $60 \%$ dzieci. Trudniejszą umiejętność - pisanie opanowało zaledwie $22 \%$, zaś liczenie - 7,5\%. Najwyższe umiejętności prezentowały dzieci w domenie Szadzko, gdyż pisać umiało około $67,5 \%$, czytać - $26,2 \%$, zaś rachować - $8,2 \%$. Widać, że jej nauczyciele mieli najwyższe umiejętności, najniższe zaś w domenie Marianowo.

Wskaźników tych, odnoszących się do szkół zimowych, nie należy przeceniać, gdyż nauka w nich trwała od jesieni do Wielkanocy. Dla rzeczywistej oceny szkolnictwa należy koniecznie uwzględnić szkoły letnie, do których w grupie omawianych szkół we wsiach domenialnych nie chodziło do szkoły 43,5\% uczniów; w domenie Szadzko - 40,3\%, zaś Marianowo - 57,3\%. W domenie Dolice 6 dni uczono w trzech szkołach (Piasecznik, Dolice, Suchań), ale tylko w Suchaniu do południa i po południu, natomiast w Sadłowie i Suchanówku tylko dwa dni od godziny 8 do 11. Ze szkół tej domeny na uwagę zasługuje placówka w Piaseczniku, której nauczyciel-zakrystian, krawiec z zawodu, absolwent seminarium nauczycielskiego w Szczecinie - Johann D. Marten, swych 62 uczniów podzielił na siedem „klas”. W dwóch pierwszych uczył znajomości liter i sylabizowania, w dwóch następnych czytania, w V-VI - pisania, zaś w VII - rachowania. Taka organizacja procesu nauczania dawała lepsze wyniki niż przeciętne, bo czytać umiało 50 uczniów, pisać 13, zaś liczyć pięciu, mimo że nauczyciel pracował w złych warunkach lokalowych (za mała izba lekcyjna). Miał nadzieję na coraz lepsze wyniki. Podobnego zdania był pastor, który dodał, że rozwojowi oświaty 
będzie sprzyjać zniesienie pańszczyzny i innych szarwarków oraz uwłaszczenie chłopów. Postulował też pilne polepszenie warunków lokalowych szkoły.

W domenie Szadzko cztery dni w tygodniu chodziły dzieci do szkoły w Krzemieńcu (także po południu) i Wapnicy. Pastorzy obu tych miejscowości zapewniali, że uczą dzieci również w niedzielę przez kilka godzin. Naukę tę zapewne utożsamiali z katechezami kościelnymi. W pozostałych pięciu wsiach nauka odbywała się do południa 2 dni w tygodniu. Niejasna jest sprawa szkoły letniej w Ciemniku, gdzie nie było lokalu szkolnego, zaś nauczyciel uczył dzieci tylko w niedziele. Pastor go chwalił oraz postulował budowę szkoły, której biedna gmina nie jest w stanie sama zbudować. Wniósł też o podwyższenie jego pensji, bo była najniższa w całym synodzie, wynosiła zaledwie 2 talary i 8 groszy, co nie zapewniało mu utrzymania i dlatego gdy nie było lekcji podejmował pracę zarobkową robotnika ${ }^{93}$. Jeszcze bardziej niezrozumiały jest katalog o szkole w Sicku, której nauczyciel miał uczyć 6 dni w tygodniu, ale dalej czytamy, że żadne dziecko z tej miejscowości latem nie chodziło do szkoły ${ }^{94}$.

O ile pastorzy nie zgłaszali potrzeby poprawy szkół łaski oraz byli bardzo wstrzemięźliwi odnośnie do szkół i patronów wsi szlacheckich, o tyle - przynajmniej niektórzy z nich - w sprawie defektów szkół i nauczycieli w domenach wynagradzanych z opłat szkolnych byli nieco bardziej wrażliwi i krytyczni. Jednocześnie podkreślali swój niemały wkład w rozwój szkolnictwa przez wizytacje i prowadzone lekcje. Pastor z Wapnicy pisał, że w niedziele uczy dzieci kilka godzin w kościele i jeszcze więcej w dni powszednie w szkole, natomiast pastor w Suchanówku zapewniał, że sam uczy tak często jak tylko może, zaś pastor z Żukowa, iż tygodniowo uczy kilka godzin przed i po południu. Jeśli mimo takiego zaangażowania duchownych wiele szkół zasługiwało na krytykę, to powodem tego była nie tylko bieda rodziców wymieniana na pierwszym miejscu przez zdecydowaną większość pastorów - ale też niechęć i niezrozumienie przez nich korzyści płynących z nauczania dzieci. Krytyczny ton wobec rodziców przebijał zwłaszcza w wypowiedziach duchowych domeny Dolice. Pastorzy zgłaszali też potrzebę podwyższenia pensji nauczycieli oraz pilnego polepszenia warunków lokalnych szkół lub budowy nowego budynku szkolnego.

Szkolnictwo wiejskie synodu dobrzańskiego w 1806 roku za reprezentatywne dla Pomorza pruskiego uznane być nie może; w większości synodów poziom szkół był niższy. Wyjątek stanowiły synody Banie, Gryfino, Kołbacz, Pyrzyce

\footnotetext{
${ }^{93}$ AP Szczecin, RS., 1594, f. 181: „Gehet, wen keine Schule, auf Tagelöhner-Arbeit”.

${ }^{94}$ Tamże, f. $174-175$.
} 
i Wierzbno, które na przełomie XVIII-XIX wieku miały porównywalnie dobrze rozwinięte szkolnictwo wiejskie, również dzięki wyjątkowo dużej liczbie szkół łaski. W tym sensie szkoły te spełniły swe zadanie, bo rzeczywiście były najlepiej zorganizowane, wyposażone w nowe podręczniki oraz uczyli w nich w zdecydowanej przewadze kwalifikowani nauczyciele, z relatywnie wysokim uposażeniem. Szkolnictwo w pozostałych synodach, od szkół w wymienionych sześciu, dzieliła przepaść W synodzie dobrzańskim na początku XIX wieku poziom szkolnictwa był wypadkową wielu procesów i długotrwałych czynników. Bez wątpienia bardzo korzystnie na jego rozwój wpływała doskonale rozwinięta sieć kościołów, która była jednym z najważniejszych czynników kształtowania sieci szkolnej już od przełomu XVII-XVIII wieku, a zwłaszcza w okresie rządów Fryderyka Wilhelma I, który tak silnie związał szkolnictwo z katechizacją i pietyzmem. Drugim sprzyjającym czynnikiem była struktura własności ziemskiej synodu, w którym dominowały państwowe domeny, przywiązujące większą wagę do realizacji aktów prawnych króla pruskiego niż szlachta. Pochodną tej struktury własności i czynnika geopolitycznego, tj. położenia w pobliżu Stargardu, czyli na obszarze manewrów wojskowych, corocznie odbywających się w obecności króla pruskiego Fryderyka II była relatywnie duża liczba nauczycieli wsi domenialnych, opłacanych z państwowego funduszu szkolnego. Szkoły te, dzięki wyższym niż przeciętne umiejętnościom i uposażeniu nauczycieli, z czasem stały się wzorcowymi państwowymi placówkami oświatowymi, dobrze zorganizowanymi i lepiej funkcjonującymi, a co najważniejsze - lepiej nauczającymi i wychowującymi dzieci.

\section{Bibliografia}

\section{Źródla archiwalne}

Archiwum Państwowe w Szczecinie

Konsystorz Ewangelicki w Szczecinie

Rękopisy i Spuścizny

\section{Literatura}

„Annalen des Preußischen Schul- und Kirchenwesens” 1800, nr 1; nr 2; nr 3.

Auszug aus einem Bericht der Pommerschen Regierung und des Pommerschen Konsistorium zu Stettin über die Verfasserung der Schulanstalten in dem Herzogtum Pommern, „Pommersch Blätter für die Schule und ihre Freunde” 1904, t. 28 (6).

Brüggemann L.W., Ausführliche Beschreibung des gegenwärtigen Zustandes des Königl. Preussischen Herzogthums Vor- und Hinterpommern, T. II, Bd. 1, Stettin 1784. 
Brüggemann L.W., Beiträge zu der ausführliche Beschreibung des Königl. Preußischen Herzogthums Vor- und Hinter-Pommern, Stettin 1806.

Bülow G. v., Beiträge zur Geschichte der Pommerschen Dorfschulen, „Evangelisches Monatsschrift für die Deutsche Schule" 1887, nr 8.

Detto A., Die Besiedlung des Oderbruches durch Friedrich den Großen, „Forschungen zur Brandenburgischen und Preußischen Geschichte" 1903, t. 16.

Dzieje Szczecina, Wiek X-1805, red. G. Labuda, Warszawa-Poznań 1987.

Dzieje ziemi bytowskiej, red. S. Gierszewski, Poznań 1972.

Dzieje ziemi drawskiej, red. T. Gasztold, Poznań 1972.

Friedaender E., Massow Julius Eberhardt von, „Allgemeine Deutsche Biographie” 1876, t. 20.

Gerlach O., Die Idee der Nationalerziehung in der Geschichte der preußischen Volksschule, Bd. 1, Langensalza-Berlin-Leipzig 1932.

Gohrbandt E., Ortsgeschichte, w: Der Kreis Rummelsburg ein Heimatbuch, red. Kreisausschuß des Kreises Rummelsburg, Stettin 1938.

Gut P., Powstanie królewskiego sądownictwa w pruskich domenach w XVIII wieku na przykładzie prowincji pomorskiej, w: Studia archiwalne - historyczne - politologiczne, red. A. Czubiński, J. Macholak, Szczecin 2003,

Heinemann M., Schule im Vorfeld der Verwaltung. Die Entwicklung der preußischen Unterrichtsverwaldung von 1771-1800, Göttingen 1974.

Henning E., David Gilly (1748-1808), „Baltische Studien” 1980, nr 66

Historia Pomorza. Tom II do roku 1815, red. i wstęp G. Labuda. Część 1 (1464/661648/57), oprac. M. Biskup, M. Bogucka, M. Mączak, B. Wachowiak, Poznań 1976.

Historia Pomorza. Tom II do roku 1815, red. G. Labuda. Część 3: Pomorze Zachodnie w latach 1648-1815, oprac. Z. Szultka, H. Lesiński, współudział D. Łukasiewicz i A. Wielopolski, Poznań 2003.

Historia Stupska, red. S. Gierszewski, Poznań 1981.

Kallaur K., Szkolnictwo elementarne w powiecie stupskim w drugiej połowie XVII wieku, w: XII Konferencja Kaszubsko-Pomorska. Szkolnictwo i oświata na Pomorzu (XVI-XXw.), red. Z. Romanow, Słupsk 2013.

Klempin R., Kratz G., Matrikeln und Verzeichnisse der pommerschen Ritterschaft vom XIV bis in das XIX Jahrhundert, Berlin 1863.

Koch F., Fürst Und die Schule; oder über die Verdienste Pommerschen Fürsten um die Schulen ihres Landes, Stettin 1821.

Leschinsky A., Roeder P.M., Schule im historischen Prozeß. Studien zur Geschichte der preußischen Elementarschule im 18. und 19. Jahrhundert, Hamburg 1976.

Łukasiewicz D., Państwo brandenbursko-pruskie wobec szkolnictwa na Pomorzu Zachodnim w latach 1648-1806, w: Szlachta - społeczeństwo - państwo między Warmia a Rugia w XVIII-XX wieku, red. M. Jaroszewicz, W. Stępiński, Szczecin 1998. 
Łukaszewicz D., Pruska szkoła na Pomorzu Zachodnim w XVII-XVIII w. Podstawy materialne. Programy nauczania. Nauczyciele, „Przegląd Historyczny” 1996, nr 1 (87).

Łukaszewicz D., Reformy szkolnictwa na Pomorzu Zachodnim w XVIII w., „Przegląd Zachodni” 1996, nr 3 (87).

Łukasiewicz D., Szultka Z., Wzrost roli państwa w przemianach systemu oświaty Pomorza pruskiego w XVIII wieku, w: Historia Pomorza. Tom II do roku 1815, red. G. Labuda. Część 3: Pomorze Zachodnie w latach 1648-1815, oprac. Z. Szultka, H. Lesiński, współudział D. Łukasiewicz i A. Wielopolski, Poznań 2003.

Massow W., Die Massows. Gesichte einer pommerscher Adelsfamilie, Halle 1931.

Moderow H., Die evangelischen Geistlichen Pommerns von der Reformation bis zur Gegenwart, T. 1. Der Regierungsbezirk Stettin, Stettin 1903.

Müller E., Die evangelischen Geistlichen Pommerns von der Reformation bis zum Gegenwart. T. II: Der Regierungsbezirk Köslin, Stettin 1912.

Neugebauer W., Das Bildungswesen in Preußen seit des Mitte des 17. Jahrhunderts, w: Handbuch der Preussischen Geschichte. Handbuch der Preussischen Geschichte, Bd. II, red. O. Büsch, Berlin-New York 1992.

Neugebauer W., Schule und Absolutismus in Preussen. Akten zum preussischen Elementarschulwesen bis 1806, Berlin-New York 1992.

Puttkamer E. v., Geschichte des Gesellechts v. Puttkamer, 2. Aufl., Neustadt a.d. Aisch 1984.

Rochow F.E., Der Kinderfreund, ein Lesebuch zum Gebrauch in Landschulen, Berlin 1772.

Rochow F.E., Versuch eines Schul-Buchs für Kinder der Land-Leute oder zum Gebrauch in Dorf-Schulen, Berlin 1772.

Schwartz P., Der erste Kulturkampf in Preussen um Kirche und Schule (1788-1798), Berlin 1925.

Schwartz P., Die Schulen der Provinz Westpreußen unter dem Oberschulkollegium 17871806, „Zeitschrift für Geschichte der Erziehung und der Unterrichts” 1926, nr 16.

Stelmach M., David Gilly i jego mapa Pomorza Zachodniego z 1789 r., „Przegląd Zachodniopomorski” 1983, z. 27.

Szultka Z., Główne linie rozwoju ludności kaszubskiej do roku 1945, w: Pomorze Zachodnie w tysiacleciu, red. P. Bartnik, K. Kozłowski, Szczecin 2000.

Szultka Z., Język polski w Kościele ewangelicko-augsburskim na Pomorzu Zachodnim od XVI do XIX wieku, Wrocław 1991.

Szultka Z., Pomorze Zachodnie prowincja państwa pruskiego (1720-1815), w: Historia Pomorza, t. III, cz. 1.

Szultka Z., Stosunek prezydenta Zarządu Pomorza i pruskiego ministra sprawiedliwości Juliusa Eberhardta W.E. v. Massowa wobec języka kaszubskiego, „Acta Cassubiana" 2012, nr 14.

Szultka Z., W państwie brandenbursko-pruskim (1648-1806).

Ślaski K., Przemiany etniczne na Pomorzu Zachodnim w rozwoju dziejowym, Poznań 1954. 
Vollmer F., Die preußische Volksschulpolitik unter Friedrich dem Größen, Berlin 1918.

Wachowiak B., W zjednoczonym Księstwie Pomorskim (1478-1648), w: Dzieje Szczecina, Wiek X-1805, red. G. Labuda, Warszawa-Poznań 1987.

Wachowiak B., Szczecin w okresie przewagi państwa feudalnego 1478-1713, w: Dzieje Szczecina, Wiek X-1805, red. G. Labuda, Warszawa-Poznań 1987.

Wachowiak B., Szkolnictwo zachodniopomorskie w okresie Odrodzenia, w: Historia Pomorza. Tom II do roku 1815, red. i wstęp G. Labuda. Część 1 (1464/66-1648/57), oprac. M. Biskup, M. Bogucka, A. Mączak, B. Wachowiak, Poznań 1976.

Wehrmann M., Geschichte von Pommern, Bd. II, Gotha 1906.

Wehrmann M., Schulwesen im Neustettiner Kreise im Jahre 1773, Unserer Heimat-Museum 22, 1928, nr 9-10.

Wehrmann M, Vom Schulwesen im Neustettiner Kreise im Jahre 1773, Unsesrer Heimat-Museum 2, 1928.

Wehrmann M., Vom Schulwesen im Kreise Greifenberg zur Zeit Friedrichs des Großen, „Greifenberger Kreiskalander“ 1925.

Wesołowska S., Materiały do dziejów szkolnictwa elementarnego w powiecie gryfickim do połowy XIX w., w: Trzebiatów - spotkania pomorskie - 2005 r., red. J. Kochanowska, Wołczkowo 2006.

Wesołowska S., Szkolnictwo wiejskie na Pomorzu w XVIII wieku-przyczynek do dziejów, w: Dzieje wsi pomorskiej: III Międzynarodowa Konferencja Naukowa, red. R. Gaziński, A. Chludziński, Dygowo-Szczecin 2004.

Wienecke F., Die Landgnadenschulen der Kurmark, w: Schulblatt für die Provinz Brandenburg, Bd. 70, 1905.

Wiśniewski J., Początki układu kapitalistycznego 1713-1805, w: Dzieje Szczecina, t. II, red. G. Labuda, Warszawa-Poznań 1985.

Wutstrack Ch. W., Kurze historisch-geographisch-statistische Beschreibung von königlich-preussischen Herzogthume Vor-und Hinter-Pommern, Stettin 1793.

Tribbensee F., Schulwesen, w: Der Kreis Rummelsburg. Ein Heimatbuch, Stettin 1938.

\section{Abstrakt}

Artykuł jest próbą ukazania celów, wdrażania i skutków systemu szkół łaski finansowanych przez państwo z funduszu szkolnego na Pomorzu pruskim w latach 1777-1807, czyli od jego ustanowienia do zaniku w warunkach okupacji Pomorza przez Francję. Chociaż ogólne cele i zasady reformy szkół wiejskich objętych tym systemem na Pomorzu były podobne jak w Marchii Elektorskiej i w Prusach Zachodnich oraz wynikały z fryderycjańskiej koncepcji monarchii absolutnej i jej podziału stanowego, to jednak w miarę upływu czasu i jego wdrażania w życie, zróżnicowanie systematycznie się pogłębiało. Melioracyjny fundusz szkolny 
prawie w całości pochodził ze środków szlacheckich, zaś w około $70 \%$ korzystały z niego szkoły w domenach (w pierwszym rzędzie wsie założone w ramach kolonizacji fryderycjańskiej), natomiast szlacheckie w około $20 \%$. W dodatku beneficjentami ostatnich środków była wyłącznie szlachta związana z wyższym korpusem oficerskim i aparatem biurokratycznym, która nie zawsze spełniała warunki uzyskania środków z funduszu. Jak krytycznie by nie oceniać system szkół łaski, stanowiących zaledwie 6\% szkół wiejskich Pomorza pruskiego, nie ulega wątpliwości, że tylko w jego nadodrzańskim pasie, szkoły te były na przełomie XVIII-XIX wieku rzeczywiście wzorowymi placówkami oświatowymi, w całości opłacanymi przez państwo, z kwalifikowanymi nauczycielami, realizującymi oświeceniowy program nauczania przy pomocy oświeceniowych metod nauczania i podręczników.

\title{
Elementary Rural Schools Financed by the Educational Fund in Prussian Pomerania in the Years 1777-1807
}

\begin{abstract}
In his article the author attempts to indicate the aims and effects of the system of schools of grace financed by the State through the educational fund in Pomerania in the years 1777-1807, i.e. from the moment the fund was set up to its demise under the French occupation of Pomerania. Although the general aims and the rules of the reforms of the rural schools in Pomerania were similar to the ones in the Electoral March and West Prussia, and although they arose from the same concept of Frederickian absolute monarchy and its division into estates, the difference between the two systems were increasing with time. Almost the whole of the school improvement fund came from the gentry, $70 \%$ of it was consumed by the schools in domains (first of all the villages founded within the framework of the Frederickian colonisation) and only $20 \%$ - by the gentry; in addition, the beneficiaries from the gentry were in their majority the nobility connected with the corps of higher officers and the bureaucratic apparatus that did not always comply with the requirements to get assistance from the fund. However critically the system of schools of grace were assessed, and they constituted only $6 \%$ of the all the schools of Prussian Pomerania, there is no doubt that at the turn of $18^{\text {th }}$ and $19^{\text {th }}$ centuries only in the regions along the Oder the schools in question were model educational institutions with qualified teachers, in its entirety financed by the State, and they implemented an Enlightenment educational programme with Enlightenment teaching methods and textbooks.
\end{abstract}

